\title{
A comprehensive sulfur and oxygen isotope study of sulfur cycling in a shallow, hyper- euxinic meromictic lake
}

William P. Gilhooly III $^{\mathrm{a}, \mathrm{b}, *}$, Christopher T. Reinhard ${ }^{\mathrm{a}, \mathrm{c}}$, Timothy W. Lyons ${ }^{\mathrm{a}}$

${ }^{a}$ Department of Earth Sciences, University of California, 900 University Avenue, Riverside, CA 92521, USA

${ }^{\mathrm{b}}$ Department of Earth Sciences, Indiana University-Purdue University Indianapolis, SL118, 723 W. Michigan Street, Indianapolis, IN 46202, USA

'School of Earth \& Atmospheric Sciences, Georgia Institute of Technology, 311 Ferst Drive, Atlanta, GA 30332, USA

*Corresponding author. Current address: Department of Earth Sciences, Indiana University-

This is the author's manuscript of the article published in final edited form as:

Gilhooly III, W. P., Reinhard, C. T., \& Lyons, T. W. (n.d.). A comprehensive sulfur and oxygen isotope study of sulfur cycling in a shallow, hyper-euxinic meromictic lake. Geochimica et Cosmochimica Acta. 


\section{Abstract}

24 Mahoney Lake is a permanently anoxic and sulfidic (euxinic) lake that has a dense plate of

25 purple sulfur bacteria positioned at mid-water depth $(\sim 7 \mathrm{~m})$ where free sulfide intercepts the

26 photic zone. We analyzed the isotopic composition of sulfate $\left(\delta^{34} \mathrm{~S}_{\mathrm{SO} 4}\right.$ and $\left.\delta^{18} \mathrm{O}_{\mathrm{SO} 4}\right)$, sulfide

$27\left(\delta^{34} \mathrm{~S}_{\mathrm{H} 2 \mathrm{~S}}\right)$, and the water $\left(\delta^{18} \mathrm{O}_{\mathrm{H} 2 \mathrm{O}}\right)$ to track the potentially coupled processes of dissimilatory

28 sulfate reduction and phototrophic sulfide oxidation within an aquatic environment with

29 extremely high sulfide concentrations $(>30 \mathrm{mM})$. Large isotopic offsets observed between sulfate

30 and sulfide within the monimolimnion $\left(\delta^{34} \mathrm{~S}_{\mathrm{SO}-\mathrm{H} 2 \mathrm{~S}}=51 \%\right.$ o $)$ and within pore waters along the oxic

31 margin $\left(\delta^{34} \mathrm{~S}_{\mathrm{SO} 4-\mathrm{H} 2 \mathrm{~S}}>50 \%\right.$ o $)$ are consistent with sulfate reduction in both the sediments and the

32 anoxic water column. Given the high sulfide concentrations of the lake, sulfur disproportionation

33 is likely inoperable or limited to a very narrow zone in the chemocline, and therefore the large

34 instantaneous fractionations are best explained by the microbial process of sulfate reduction.

35 Pyrite extracted from the sediments reflects the isotopic composition of water column sulfide,

36 suggesting that pyrite buried in the euxinic depocenter of the lake formed in the water column.

37 The offset between sulfate and dissolved sulfide decreases at the chemocline $\left(\delta^{34} \mathrm{~S}_{\mathrm{SO} 4-\mathrm{H} 2 \mathrm{~S}}=\right.$

38 37\%o), a trend possibly explained by elevated sulfate reduction rates and inconsistent with

39 appreciable disproportionation within this interval. Water column sulfate exhibits a linear

40 response in $\delta^{18} \mathrm{O}_{\mathrm{SO} 4}-\delta^{34} \mathrm{~S}_{\mathrm{SO} 4}$ and the slope of this relationship suggests relatively high sulfate

41 reduction rates that appear to respond to seasonal changes in the productivity of purple sulfur

42 bacteria. Although photosynthetic activity within the microbial plate influences the $\delta^{18} \mathrm{O}_{\mathrm{SO}}-\delta^{34} \mathrm{~S}$

43 relationship, the biosignature for photosynthetic sulfur bacteria is restricted to the oxic/anoxic

44 transition zone and is apparently minor relative to the more prevalent process of sulfate reduction

45 operative throughout the light-deprived deeper anoxic water column and sediment pore waters. 


\section{Introduction}

48 Sulfur isotope compilations of sedimentary pyrite and sulfates (gypsum, barite, carbonate49 associated sulfate) have provided proxy evidence for the increase in atmospheric oxygen from

50 the Archean to the present. Three distinct stages have been recognized in the sulfur isotope 51 record based on mass conservative $\left({ }^{34} \mathrm{~S} /{ }^{32} \mathrm{~S}\right)$ and mass-independent $\left({ }^{33} \mathrm{~S} /{ }^{32} \mathrm{~S}\right)$ fractionation effects.

52 Small $\delta^{34} \mathrm{~S}$ fractionations (Canfield, 1998), associated with low oceanic sulfate levels $(<2.5 \mu \mathrm{M})$

53 in the Archean (Habicht et al., 2002; Crowe et al., 2014), are congruent with $\Delta^{33} \mathrm{~S}$ photochemical

54 isotope effects preserved under low atmospheric oxygen levels (Farquhar et al., 2000). This

55 stage ends with the Great Oxidation Event marked by an increase in $\delta^{34} \mathrm{~S}$ fractionations

56 coincident with the loss of mass-independent signatures 2.3-2.4 billion years ago (Bekker et al.,

57 2004), indicating that oxygen accumulated to significant concentrations in the atmosphere. The

58 third state, characterized by frequently large fractionations perhaps linked to a strongly oxidative

59 sulfur cycling and analogous to isotopic patterns seen today $\left(\Delta^{34} \mathrm{~S}_{\text {sulfate-sulfide }}>50 \%\right.$ o , commenced

60 during the Neoproterozoic (1050 to 640 million years ago) (Canfield \& Teske, 1996; Canfield, $612001)$

62

63 The isotopic offset $\left(\Delta^{34} S_{\text {sulfate-sulfide }}=\delta^{34} S_{\text {sulfate }}-\delta^{34} S_{\text {sulfide }}\right)$ imparted during dissimilatory sulfate

64 reduction can be large in magnitude, with $\Delta^{34} \mathrm{~S}_{\text {sulfate-sulfide }}$ exceeding $60 \%$ (Canfield et al., 2010;

65 Sim et al., 2011), or muted $(\sim 0 \%)$ at low sulfate concentrations (Harrison \& Thode, 1958;

66 Habicht et al., 2002). Similar offsets are produced by the oxidative sulfur cycle, ranging from the

67 potentially large isotope effects $(\sim 20 \%$ ) that can occur during sulfur disproportionation

68 (Canfield \& Thamdrup, 1994; Habicht et al., 1998; Böttcher et al., 2001) to small isotope effects

$69( \pm 5 \%$ ) produced during chemolithotrophic sulfide oxidation (Fry et al., 1986) and anoxygenic 
70 photosynthesis (Fry et al., 1984; Fry, 1986; Zerkle et al., 2009; Brabec et al., 2012). An

71 otherwise robust biosignature for sulfate reduction in modern sediments thus becomes non-

72 diagnostic under sulfate-limited conditions as postulated for the Archean ocean or periods of

73 rapid expansion of the oceanic sulfate pool such as the Neoproterozoic, when many reactions

74 within the biologically mediated sulfur cycle may be operative. For example, the yarious

75 explanations for an increase in the magnitude of sulfur isotope fractionations during the

76 Neoproterozoic include an increased prominence of nonphotosynthetic oxidative sulfur

77 metabolisms and associated disproportionation of the resulting intermediate sulfur species

78 (Canfield \& Teske, 1996; Johnston et al., 2005; Fike et al., 2006), reoxidation effects mediated

79 by the onset of bioturbation (Canfield \& Farquhar, 2009), and possibly reservoir effects linked

80 with rising and falling sulfate concentrations within an evolving oceanic sulfur pool (Hurtgen et

81 al., 2005).

82

83 The isotopic composition of oxygen bound in sulfate $\left(\delta^{18} \mathrm{O}_{\mathrm{SO} 4}\right)$ may provide an additional vector

84 to better interpret the microbial processes responsible for sulfate synthesis and cycling over

85 geologic timescales. Provided the associated isotope effects are constrained, $\delta^{18} \mathrm{O}_{\mathrm{SO} 4}$ can be a

86 powerful tool for tracing the ultimate source of sulfate to the ocean, given that the oxygen

87 incorporated into the sulfate during sulfide oxidation can derive from either ambient water $\left(\mathrm{H}_{2} \mathrm{O}\right)$

88 or the atmosphere $\left(\mathrm{O}_{2}\right)$. On a global basis, gypsum dissolution and oxidative pyrite weathering

89 (the inputs) balance the outputs via evaporite precipitation and sulfate reduction with

90 concomitant pyrite burial (Holser et al., 1979; Claypool et al., 1980). Tracking the sulfate-

91 oxygen budget through these isotopically distinct reservoirs is complicated by oxygen isotope

92 exchange at low pH (Hoering \& Kennedy, 1957; Lloyd, 1968; Chiba \& Sakai, 1985), post- 
93 diagenetic alteration (Turchyn et al., 2009), and numerous other processes that overprint the

94 oxygen isotope composition of sulfate (Bottrell \& Newton, 2006; Turchyn \& Schrag, 2006).

96 Sulfur isotopes are relatively insensitive to inorganic sulfide oxidation effects, but sulfate formed

97 from sulfide oxidation will carry different proportions of oxygen derived from water $\left(\delta^{18} \mathrm{O} \leq\right.$

$980 \%$ and/or atmospheric oxygen $\left(\delta^{18} \mathrm{O}=23.5 \%\right.$ ) depending on the oxidation pathway (Taylor \&

99 Wheeler, 1984; van Everdingen \& Krouse, 1985; Balci et al., 2007; Calmels et al., 2007; Balci et

100 al., 2012). The oxidation of sulfide coupled to iron reduction derives oxygen entirely from water

101 and results in $\delta^{18} \mathrm{O}_{\mathrm{SO} 4}$ values lower than those produced by oxidation with molecular oxygen

102 (Calmels et al., 2007). Hydrothermal sulfur inputs $(\sim 0 \%$ ) may be difficult to differentiate from

103 biological cycling within a low sulfate reservoir; however, $\delta^{18} \mathrm{O}_{\mathrm{sO}}$ produced by photosynthetic

104 bacteria may reflect the isotopic composition of the parent water (Brabec et al., 2012).

105

106 Environmental conditions in the Paleo- and Mesoproterozoic, when atmospheric oxygen

107 concentrations were still relatively low, and large portions of the oceans were anoxic and sulfidic

108 (euxinic), were conducive to widespread carbon fixation by anoxygenic photosynthesis

109 (Johnston et al., 2009). Phototrophic sulfur bacteria oxidize sulfide and fix carbon dioxide in the

110 presence of sunlight without producing oxygen. Sulfide is oxidized to intracellular elemental

111 sulfur, and the internal sulfur stores are ultimately oxidized to sulfate when sulfide becomes

112 limiting $(<1 \mathrm{mM})$ (Overmann \& Pfennig, 1992). In the geologic record, this ecological niche is

113 termed "photic zone euxinia," and organic biomarkers of sulfide-oxidizing phototrophs can

114 provide proxy evidence for free sulfide at shallow depths in the water column (Brocks et al.,

115 2005; Brocks \& Schaeffer, 2008) provided the organisms were pelagic (Meyer et al., 2011). 
116 Biological oxidation of sulfide by anoxygenic photosynthesis may have contributed to the

117 formation of sulfate in the Proterozoic water column (Johnston et al., 2009). With limited

118 organic biomarker and geochemical evidence for widespread primary production by anoxygenic

119 sulfur bacteria (Lyons et al., 2004), and the potential for metabolic overlap with cyanobacteria

120 capable of sulfide oxidation but without a distinctive biomarker signature for this process

121 (Johnston et al., 2009), additional proxies are needed to fingerprint the paleoecological and

122 biogeochemical signals associated with euxinia in the photic zone. Paired $\delta^{34} \mathrm{~S}$ and $\delta^{18} \mathrm{O}$ data

123 from ancient sulfates (gypsum, barite, or carbonate-associated-sulfate) may offer an additional

124 constraint on the history and ecological distribution of photosynthetic S-oxidation. Sulfate-

125 oxygen can fractionate during sulfate reduction, but the extent of isotopic enrichment is

126 controlled either by kinetic isotope effects imparted during intracellular enzymatic steps or

127 equilibrium oxygen exchange with ambient water (Brunner et al., 2005; Brunner et al., 2012;

128 Antler et al., 2013). An improved understanding of these processes can be gained from modern

129 natural environments.

130

131 The primary objective of this study was to track microbial sulfur oxidation and reduction in

132 density stratified Mahoney Lake as a modern analog for biotic pathways that may have generated

133 oxidants in Earth's early ocean. Free dissolved sulfide $\left(\left[\mathrm{H}_{2} \mathrm{~S}\right]=30 \mathrm{mM}\right)$ in the photic zone of the

134 water column supports a perennial plate of purple sulfur bacteria (Northcote \& Halsey, 1969;

135 Northcote \& Hall, 1983; Overmann et al., 1991; Overmann et al., 1996). The purple sulfur

136 bacterium is a member of Chromatiaceae and is designated as strain ML1 (Hamilton et al.,

137 2014). Although found at mid-water depth of the lake, ML1 is most closely related to a marine

138 benthic purple sulfur bacteria Thiohalocapsa (Hamilton et al., 2014). Such observations have 
139 significance when relating biomarker distribution to microbial ecology and inferred

140 environmental conditions (Meyer et al., 2011). The euxinic conditions are broadly consistent

141 with chemical properties for many Proterozoic ocean models (Reinhard et al., 2013). However,

142 the lake also has high sulfate concentrations $\left(\left[\mathrm{SO}_{4}\right]>300 \mathrm{mM}\right)$ that are inconsistent with early

143 analogs and indeed are more than ten times the concentration in the modern ocean. At the same

144 time, the large reservoir helps maximize the isotopic offset for sulfate reduction $\left(\Delta^{34} \mathrm{~S}_{\text {sulfate-sulfide }}\right.$

$145>50 \%$ ). In other words, the isotopic offsets are controlled by biological processing rather than by

146 the size of the sulfate pool. The biosignature for dissimilatory sulfate reduction in Mahoney Lake

147 is thus distinct from the small offsets produced under sulfate-limited conditions that would

148 otherwise overlap with sulfur isotope fractionations produced by sulfide oxidizing phototrophic

149 bacteria. As such, Mahoney Lake provides a novel natural laboratory for studying sulfur cycling.

150 We present paired sulfur and oxygen isotope compositions of dissolved sulfate $\left(\delta^{34} \mathrm{~S}_{\mathrm{SO} 4}\right.$ and

$151 \delta^{18} \mathrm{O}_{\mathrm{SO} 4}$ ) relative to the sulfur isotope properties of product sulfides (either dissolved or

152 sedimentary) to explore isotope effects associated with sulfate reduction and anaerobic sulfide

153 oxidation (and thus biologically mediated sulfate generation) by anoxygenic photosynthetic

154 bacteria.

155

156 2. Materials and Methods

157 Site description

158 Mahoney Lake $\left(49^{\circ} 17^{\prime} \mathrm{N} ; 119^{\circ} 35^{\prime} \mathrm{W}\right.$; elevation $\left.47.15 \mathrm{~m}\right)$ is a permanently stratified (meromictic)

159 lake in the Okanagan Valley, British Columbia (Figure 1). Within the same catchment, Green

160 Lake $\left(49^{\circ} 18^{\prime} \mathrm{N}, 119^{\circ} 34^{\prime} \mathrm{W}, 490.7 \mathrm{~m}\right)$ fully mixes during fall and spring overturn (dimictic). Both

161 are shallow $(\sim 15 \mathrm{~m})$, saline, terminal lakes. The Okanagan Valley is an arid region within the 
162 southern interior of a province that receives an average of $265 \mathrm{~mm}$ of total annual precipitation

163 (rain and snow). Mean monthly temperatures range from $-14.3^{\circ} \mathrm{C}$ to $23.5^{\circ} \mathrm{C}$

164 (www.climate.weatheroffice.gc.ca; station 1126150; precipitation and temperature records 1941

165 to 2010).

167 The lake drainage area is located within an extensional basin known as the White Lake Basin

168 (Figure 1). The regional geology is dominated by a complex series of normal faults, fractured

169 bedding planes, and jointed volcanic formations that promote groundwater circulation (Lewis,

170 1984; Michel et al., 2002). Both lakes straddle a north-south trending fault line that bisects the

171 drainage basin (Northcote \& Hall, 1983). The bedrock geology to the east of the fault is

172 comprised of cherts, greenstones, schists, and granitic intrusions (Northcote \& Hall, 1983;

173 Church, 2002) (Figure 1). The western extent of the catchment contains ultramafic volcanic

174 rocks and lavas (Northcote \& Hall, 1983; Church, 2002). Salts (Na-Ca-Mg-SO $)_{4}$ derived from

175 the weathering of metavolcanic rocks from the Marron Formation (Eocene) in the surrounding

176 watershed contribute to the high conductivity and total dissolved solid load of Mahoney Lake

177 (Northcote \& Hall, 1983).

178

179 Mahoney Lake $\left(136.2 \times 10^{4} \mathrm{~m}^{3}, 19.8 \mathrm{ha}, 6.9 \mathrm{~m}\right)$ and Green Lake $\left(113.6 \times 10^{4} \mathrm{~m}^{3}, 12.6 \mathrm{ha}, 9.0 \mathrm{~m}\right)$

180 have similar volumes, surface areas, and mean depths (Northcote \& Hall, 1983). Although the

181 dimensions of the lakes are comparable, water column redox conditions are strikingly different.

182 The Mahoney Lake monimolimnion persistently contains dissolved sulfide, whereas bottom

183 waters in Green Lake are perennially saturated with oxygen. The similar physical features

184 suggest other factors are responsible for meromixis in Mahoney Lake. Northcote and Hall (1983) 
185 proposed that the hills surrounding Mahoney shelter the lake from prevailing winds and thus

186 wind-blown mixing. In contrast, Green Lake is exposed to strong northeasterly winds that

187 routinely mix the water column (Ward et al., 1989; Ward et al., 1990).

189 Sediments and pore waters were extracted from Cores 2 and 3 collected within the euxinic water 190 mass from the deepest portion of Mahoney Lake in September 2006; Core 9 was collected at the

191 same time along the oxic margin above the chemocline (Figure 1). Water column samples were 192 also collected from Green Lake as a reference for oxic conditions in a saline lake. Water column 193 samples were collected from Mahoney Lake in September 2006 and July 2008. During the later 194 trip, water was also sampled from a shallow pond $(<1 \mathrm{~m})$ in the hills to the west ('ML pond') 195 and from Sleeping Lake to the east (Figure 1).

197 Water column sampling

198 Photosynthetically available radiation was measured with a spherical light sensor (LI-193, LI199 COR Environmental, Lincoln, NE, USA). Light attenuation above and below the microbial plate 200 was determined according to Beer-Bouguer's Law:

201

202

$$
\mathrm{I}_{\mathrm{z}}=\mathrm{I}_{\mathrm{o}} \mathrm{e}^{-\mathrm{kz}}
$$

where radiation incident at depth $\left(\mathrm{I}_{\mathrm{Z}}\right)$ is proportional to the light intensity from the surface $\left(\mathrm{I}_{\mathrm{o}}\right)$ 205 and the extinction coefficient (k) at a given depth (z). Turbidity was measured as an indication of 206 water clarity and microbial biomass (2020c Turbidimeter, LaMotte Company, Chestertown, MD, 207 USA). Water column $\mathrm{pH}$, temperature, specific conductivity, and dissolved oxygen profiles were 
measured in situ with a handheld meter and probe (Quanta, Hydrolab, Loveland, CO, USA).

209 Water column samples were collected with a battery-powered pump at depth intervals of 10 to

$210100 \mathrm{~cm}$. High-resolution samples were also collected in the water column with a syringe sampler

211 that allowed sampling at fixed intervals $(10 \mathrm{~cm})$ with minimal disturbance of the chemocline.

212 The dissolved oxygen meter was attached to the base of the syringe sampler, and the position of

213 the syringe ports relative to the location of the oxic-anoxic interface was determined from the

214 oxygen concentrations measured in situ and the known distance between the syringes and the

215 probe. Samples from the water column collected for sulfide analysis were preserved with 3\%

216 (wt./volume) zinc acetate solution for concentration determinations or precipitated with cadmium

217 acetate for sulfur isotope analysis. A subset of samples from the water column was taken for

218 elemental sulfur were filtered onto $0.2 \mu \mathrm{m}$ polyestersulfone filters (Millipore) under nitrogen

219 atmosphere and stored frozen at $-20^{\circ} \mathrm{C}$.

220

\section{Sediments and pore waters}

222 Lake sediments were collected with a modified gravity-piston corer (Fisher et al., 1992).

223 Sediment cores were capped, sealed, and taken to the field laboratory for processing within hours

224 of collection. Sediments were sectioned and extruded in a nitrogen-filled glovebag. Surfaces of

225 the whole-round mud samples in contact with the core liner were scrapped to remove potential

226 lake water contamination and to minimize the effects of smearing. Pore waters were extracted by

227 centrifugation and filtered through $0.2 \mu \mathrm{m}$ syringe filters. Pore water splits were preserved for

228 sulfide concentrations with 3\% (wt./volume) zinc acetate solution or precipitated with cadmium

229 acetate for sulfur isotope analysis. Sediment samples were then purged with nitrogen gas, frozen,

230 and transported to our labs in Riverside for subsequent analyses. 


\section{Analytical}

233 Sedimentary sulfides were extracted from wet, freshly thawed sediment by sequential

234 extractions. Water content was determined by weighing separate sediment splits before and after

235 drying and corrected for mass addition from salts that precipitated during sample drying in order

236 to present the data as wt.\% on a dry sediment basis. Acid volatile sulfides (AVS; FeS) were

237 extracted with a room temperature solution of $6 \mathrm{~N} \mathrm{HCl}$ and $15 \%$ (wt./volume) stannous chloride

238 (Chanton \& Martens, 1985; Cornwell \& Morse, 1987). The extractant was subsequently

239 separated from the sediment by filtration onto a glass fiber filter, and chromium reducible sulfide

240 (CRS; pyrite and elemental sulfur) was then liberated from the filtered residue by reaction with a

241 solution of boiling $1 \mathrm{M}$ chromous chloride and concentrated $\mathrm{HCl}$ (Canfield et al., 1986).

242 Chromium reducible sulfide (dominantly pyrite in this case) was also extracted from a

243 greenstone rock sample collected within the catchment. Hydrogen sulfide evolved from these

244 distillations was trapped in $3 \%$ zinc acetate solution for concentration measurements by

245 iodometric titration or precipitated as $\mathrm{Ag}_{2} \mathrm{~S}$ in a solution of $3 \%$ silver nitrate and $10 \%$ ammonium

246 hydroxide for sulfur isotope analysis (wt./volume).

247

248 The degree of sulfurization (DOS) (Boesen \& Postma, 1988; Raiswell et al., 1994) was 249 determined according to the relationship:

$\mathrm{DOS}=\frac{\mathrm{Fe}_{\mathrm{AVS}}+\mathrm{Fe}_{\mathrm{py}}}{\mathrm{Fe}_{\mathrm{AVS}}+\mathrm{Fe}_{\mathrm{py}}+\mathrm{Fe}_{\mathrm{HCl}}}$

252 where $\mathrm{Fe}_{\mathrm{AvS}}$ and $\mathrm{Fe}_{\mathrm{py}}$ are the concentrations of AVS-iron and pyrite-iron calculated from 253 extracted concentrations of AVS-sulfur and pyrite-sulfur and assuming the respective 
254 stoichiometries of $\mathrm{FeS}$ and $\mathrm{FeS}_{2}$. Reactive iron, $\mathrm{Fe}_{\mathrm{HCl}}$, was extracted from dried sediment with

255 boiling $12 \mathrm{~N} \mathrm{HCl}$ (Berner, 1970; Raiswell et al., 1988), and extractable iron concentrations were

256 measured by the Ferrozine colorimetric method (Stookey, 1970). High DOS values, approaching

257 unity in extreme cases, indicate formation and accumulation of sedimentary iron-sulfide minerals

258 under euxinic (iron-limited) conditions.

260 Dissolved sulfide in the water column and pore waters was preserved in the field with zinc

261 acetate or cadmium acetate followed by centrifugation, and aliquots of the supernatant were

262 isolated for determining chloride and sulfate concentrations. Dissolved sulfide concentrations

263 were determined colorimetrically (Cline, 1969). Sulfate concentrations were measured

264 gravimetrically or as dissolved S by ICP-MS with Xe as the collision cell gas (Agilent 7400

265 Quadrupole ICP-MS). Sulfate concentrations determined by either method agreed within $\pm 5 \%$.

266 Chloride concentrations were measured by titration (DP-957M Digital Chloridometer, Haake

267 Buchler Instruments Inc., Saddlebrook, NJ, USA). Supernatant splits were also taken for sulfur

268 and oxygen isotope analysis of sulfate. The addition of zinc acetate to water column and pore

269 water samples caused the dissolved sulfide to precipitate immediately and thus precluded

270 secondary sulfate contributions from sulfide oxidation. Sulfate was precipitated as $\mathrm{BaSO}_{4}$ by

271 addition of saturated $\mathrm{BaCl}_{2}$ solution $(250 \mathrm{~g} / \mathrm{L})$ followed by brief acidification $(4 \mathrm{~N} \mathrm{HCl})$ to

272 remove carbonates, rinsing to neutral $\mathrm{pH}$, and drying. Elemental sulfur was extracted from

273 filters collected from the water column onto copper turnings using hexane and sonication, which

274 was subsequently liberated by chromium reduction (Canfield et al., 1986) and trapped in silver

275 nitrate. Sulfides fixed as CdS in the field were rinsed with deionized water and reprecipitated as

$276 \mathrm{Ag}_{2} \mathrm{~S}$ by addition of $3 \%$ silver nitrate and $10 \%$ ammonium hydroxide (wt./volume). Precipitates 
277 of sulfate $\left(\mathrm{BaSO}_{4}\right)$ and sulfide $\left(\mathrm{Ag}_{2} \mathrm{~S}\right)$ derived from sediment extracts or dissolved species were

278 dried and homogenized with agate mortar and pestle prior to isotopic analysis.

280 Isotope compositions were expressed according to the equation:

281

$\delta^{x} \mathrm{E}=\left[\left(R_{\text {sample }} / R_{\text {standard }}\right)-1\right] \times 1000$

283

284 where ${ }^{x} \mathrm{E}$ is the given isotope $\left({ }^{2} \mathrm{H},{ }^{18} \mathrm{O}\right.$, or $\left.{ }^{34} \mathrm{~S}\right)$, and $R$ is the ${ }^{2} \mathrm{H} /{ }^{1} \mathrm{H},{ }^{18} \mathrm{O} /{ }^{16} \mathrm{O}$, or ${ }^{34} \mathrm{~S} /{ }^{32} \mathrm{~S}$ ratio 285 relative to the respective international standards for $\mathrm{H}$ and $\mathrm{O}(\mathrm{V}-\mathrm{SMOW})$, and $\mathrm{S}$ (V-CDT). 286 Water column samples were distilled prior to hydrogen and oxygen isotope analysis (West et al., 287 2006) and analyzed at the Purdue Stable Isotope Facility, Purdue University, using a Thermo288 Chemical Elemental Analyzer coupled with a stable isotope ratio mass spectrometer (TCEA289 IRMS; Delta V; ThermoElectron, Bremen, Germany). Analytical precision was better than $290 \pm 0.1 \%$ o for $\delta \mathrm{D}_{\mathrm{H} 2 \mathrm{O}}$ and $\pm 0.2 \%$ o for $\delta^{18} \mathrm{O}_{\mathrm{H} 2 \mathrm{O}}$. Sulfur isotope ratios of the sulfide phases and sulfur 291 and oxygen isotopes of sulfate were analyzed on a Delta V Plus IRMS (ThermoElectron, 292 Bremen, Germany) at the Department of Earth Sciences, University of California, Riverside. 293 Samples precipitated as either $\mathrm{Ag}_{2} \mathrm{~S}$ or $\mathrm{BaSO}_{4}$ were weighed into tin capsules with a ten-fold 294 excess of $\mathrm{V}_{2} \mathrm{O}_{5}$ for a final sample mass of $\sim 50 \mu \mathrm{g}-\mathrm{S}$ and combusted on an ECS elemental 295 analyzer (Costech Analytical, USA) coupled under continuous flow to the IRMS. $\delta^{34} \mathrm{~S}_{\mathrm{BaSO}}$ 296 values were normalized to international standards NBS-127 (21.1\%o), IAEA SO-5 (0.49\%o), and 297 IAEA SO-6 (-34.05\%o). Values for $\delta^{34} \mathrm{~S}_{\mathrm{Ag} 2 \mathrm{~S}}$ were normalized to IAEA standards S1 (-0.3\%o), S2 $298(22.65 \% \circ)$, and S3 $\left(-32.5 \%\right.$ ). $\delta^{18} \mathrm{O}_{\mathrm{SO} 4}$ values were determined by TCEA-IRMS and calibrated 299 against NBS-127 (8.7\%o), IAEA SO-5 (12.0\%o), and IAEA SO-6 (-11.0\%o). Reproducibility of 
300

301

302

303

304

305

306

307

308

309

310

311

312

313 The models are sensitive to the ratio of the forward and backward fluxes $(X=\mathrm{b} / \mathrm{f})$ of sulfur

314 within the cell and the associated kinetic isotope fractions $(\varepsilon)$ that occur during three steps in the

315 sulfate reduction network. The steps include sulfate uptake into the cell $\left(X_{1} ; \varepsilon^{34} \mathrm{~S}=-3 \%\right.$; $\varepsilon^{18} \mathrm{O}=-$

$3160.75 \%$ ), the reduction of adenosine $5^{\prime}$-phosphosulfate (APS) to sulfite $\left(X_{2} ; \varepsilon^{34} \mathrm{~S}=25 \%\right.$; $\varepsilon^{18} \mathrm{O}=$

$3176.25 \%$ ) , and the reduction of sulfite to sulfide $\left(X_{3} ; \varepsilon^{34} \mathrm{~S}=25 \%\right.$; $\varepsilon^{18} \mathrm{O}=6.25 \%$ ) (Mizutani \&

318 Rafter, 1969; Rees, 1973; Antler et al., 2013). The $\delta^{18} \mathrm{O}-\delta^{34} \mathrm{~S}$ isotope pattern is linear (Trend A)

319 when there is no reverse flux of sulfur $\left(X_{1} \cdot X_{3}=0\right)$ according to the equation,

$\delta^{18} \mathrm{O}_{\mathrm{SO}_{4(\mathrm{t})}}=\frac{\varepsilon^{18} \mathrm{O}_{\text {total }}}{\varepsilon^{34} \mathrm{~S}_{\text {total }}} \cdot\left(\delta^{34} \mathrm{~S}_{\mathrm{SO}_{4(\mathrm{l})}}-\delta^{34} \mathrm{~S}_{\mathrm{SO}_{4(0)}}\right)+\delta^{18} \mathrm{O}_{\mathrm{SO}_{4(\mathrm{o})}} \cdot$ 
323 The relationship is non-linear (Trend B) when intracellular recycling (back reaction) occurs

324 during sulfate reduction $\left(0<X_{1} \cdot X_{3}<1\right)$ where,

325

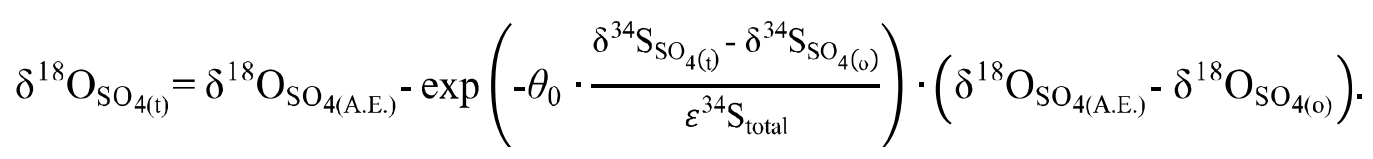

328 The residual sulfate $\left(\delta^{18} \mathrm{O}_{\mathrm{SO}_{4(\mathrm{t})}}\right)$ produced by the process of microbial sulfate reduction can thus 329 be a linear function (Equation 4) of the total fractionation factors for sulfur and oxygen isotopes $330\left(\varepsilon^{34} \mathrm{~S}_{\text {total }}\right.$ and $\left.\varepsilon^{18} \mathrm{O}_{\text {total }}\right)$, the sulfur isotope composition of residual sulfate $\left(\delta^{34} \mathrm{~S}_{\mathrm{SO}_{4(\mathrm{t})}}\right)$, the initial

331 isotopic compositions of sulfate $\left(\delta^{34} \mathrm{~S}_{\mathrm{SO}_{4(0)}}\right.$ and $\left.\delta^{18} \mathrm{O}_{\mathrm{SO}_{4(\mathrm{o})}}\right)$. The oxygen isotope composition of 332 sulfate at apparent equilibrium $\left(\delta^{18} \mathrm{O}_{\mathrm{SO}_{4(\text { A.E. })}}\right)$ and the relationship $\left(\theta_{0}\right)$ between oxygen isotope 333 exchange and the rate of sulfate reduction [where $\theta_{0}=\left(X_{1} \cdot X_{3}\right) /\left(1-X_{1} \cdot X_{3}\right)$ ] become critical 334 parameters in non-linear datasets (Equation 5).

337 Isotopic composition $\left(\delta^{34} S_{S O 4}, \delta^{8} O_{S O 4}, \delta^{8} O_{H 2 O}\right)$ of surface waters

338 The $\delta^{34} \mathrm{~S}_{\mathrm{SO} 4}\left(22.1 \%\right.$ ) and $\delta^{18} \mathrm{O}_{\mathrm{SO} 4}(16.7 \%$ ) values of surface-water sulfate collected from the 339 upper meter of the Mahoney Lake water column resembled dissolved sulfate values in the ML 340 pond (Figure 1). In contrast, the isotopic composition of sulfate in Green Lake $\left(\delta^{34} \mathrm{~S}_{\mathrm{SO}}=1.4 \%\right.$ o 341 and $\delta^{18} \mathrm{O}_{\mathrm{SO} 4}=10.8 \%$ ) and Sleeping Lake $\left(\delta^{34} \mathrm{~S}_{\mathrm{SO} 4}=1.6 \%\right.$ and $\delta^{18} \mathrm{O}_{\mathrm{SO} 4}=10.9 \%$ ) were relatively

342 depleted in ${ }^{34} \mathrm{~S}$ and ${ }^{18} \mathrm{O}$. The low $\delta^{34} \mathrm{~S}$ values of Green and Sleeping lakes were consistent with a 343 greenstone sample collected to the east of Mahoney Lake $\left(\delta^{34} S_{\text {Greenstone }}=0.8 \%\right.$ ). 
345 Surface waters collected from shallow domestic wells and numerous lakes in the area exhibit

346 high $\delta^{18} \mathrm{O}$ and $\delta \mathrm{D}$ driven by intense rates of evaporation within the arid Okanagan Valley (Figure

3472 and references cited therein). Vertical profiles exhibit little variation within the mixolimnion

$348\left(\delta^{18} \mathrm{O}_{\mathrm{H} 2 \mathrm{O}} \approx 0.8 \%\right.$ ) and decrease abruptly across the chemocline to lower values $\left(\delta^{18} \mathrm{O}_{\mathrm{H} 2 \mathrm{O}} \approx\right.$

$349-1.5 \%$ ) within the monomolimnion (Figure 2; Table 1). The slope of the local evaporation line

350 (4.7) is consistent with evaporation trends observed in hydrologically closed northern latitude

351 lakes (Gibson et al., 2002; Gibson et al., 2005) (Figure 2).

\section{Water column chemistry}

354 Representative profiles of water column dissolved oxygen, specific conductivity, temperature, 355 and $\mathrm{pH}$ demonstrate the sharp redox contrast between Green Lake and Mahoney Lake (Figure 356 3A). Green Lake is well mixed to a depth of $9 \mathrm{~m}$ and oxygenated throughout the water column.

357 In contrast, dissolved oxygen in Mahoney Lake is consumed within $7 \mathrm{~m}$ water depth. The 358 specific conductivity of Mahoney surface waters $(\sim 43 \mathrm{mS} / \mathrm{cm})$ is elevated relative to Green Lake 359 salinities by an order of magnitude. Conductivity increased 1.5 -fold within the monomolimnion 360 of Mahoney. Water temperatures below the chemocline are isothermal $\left(\sim 9^{\circ} \mathrm{C}\right)$ and remain highly 361 stable relative to inter-annual fluctuations in surface water temperatures (Northcote \& Halsey, 362 1969; Northcote \& Hall, 1990; Ward et al., 1990).

364 Redox conditions in Mahoney Lake in September 2006 were equivalent to observations made in 365 July 2008 (compare Figure 3A and 3B). The chemocline was positioned at approximately $7 \mathrm{~m}$ 
during both years. The maximum sulfide concentrations in the water column were extremely high, ranging from $36 \mathrm{mM}$ (2006) to $41 \mathrm{mM}$ (2008).

The plate of purple sulfur bacteria was positioned at the pycnocline where sunlight enters sulfidic water (Figure 3B). Extinction coefficients increased from the mixolimnion $(k=0.400)$ to the

371 quantitative absorption of sunlight below the plate $(k=3.347)$ such that less than $0.01 \%$ of incident light penetrated below $8 \mathrm{~m}$ water depth. Turbidity is highest within the microbial plate

373 (Figure 3B). Abundant levels of polysulfides and elemental sulfur (Overmann et al., 1996;

374 Overmann, 1997) likely contribute to the yellow color of the monomolimnion.

Respective chloride and sulfate concentrations averaged $57.7 \pm 1.7 \mathrm{mM}$ and $341.8 \pm 20.1 \mathrm{mM}$ in the upper $5 \mathrm{~m}$ of the mixolinion (Figure 4) of Mahoney Lake. Chloride concentrations increased to approximately $70 \mathrm{mM}$ in the monimolimnion; bottom-water sulfate concentrations were $\sim 500$ mM. Molar $\mathrm{SO}_{4} / \mathrm{Cl}$ ratios also increased within the bottom waters. Vertical profiles collected

380 during the two field studies were broadly consistent, with the exception of maxima for sulfate 381 and chloride concentrations positioned above the chemocline at 6.3 to $6.6 \mathrm{~m}$ water depth (2006, 382 Figure 4), respectively, coincident with a localized decrease in dissolved oxygen concentrations.

\section{Isotopic composition $\left(\delta^{34} S_{H 2 S}, \delta^{44} S_{S O 4}, \delta^{8} O_{S O 4}\right)$ of the Mahoney Lake water column}

385 The $\delta^{34} \mathrm{~S}_{\mathrm{SO} 4}$ and $\delta^{18} \mathrm{O}_{\mathrm{SO} 4}$ values for samples collected in September 2006 and July 2008 were 386 similar (Table 1). Relative to the surface, dissolved sulfate exhibited rapid enrichments in ${ }^{34} \mathrm{~S}$ and

$387{ }^{18} \mathrm{O}$ across the chemocline and remained fairly constant down to the sediment-water interface 388 (Figure 4). $\delta^{34} \mathrm{~S}_{\mathrm{SO} 4}$ values within the mixolimnion averaged $22.1 \pm 0.2 \%$ ( $\left.\mathrm{n}=34\right)$ and increased 
389

390

391

392

393

394

395

396

397

398

399

400

401

402

403

404

405

406

407

408

409

410

411

to $27.7 \pm 0.5 \%$ o $(\mathrm{n}=16)$ within $0.5 \mathrm{~m}$ below the chemocline. $\delta^{18} \mathrm{O}_{\mathrm{SO} 4}$ values averaged $17.1 \pm$ $0.4 \%$ ( $(\mathrm{n}=34)$ above the chemocline and increased to $20.0 \pm 0.6 \%$ o $(\mathrm{n}=34)$ within the monimolimnion (7.5 $\mathrm{m}$ to bottom). The $\sim 5.6 \%$ increase in $\delta^{34} \mathrm{~S}_{\mathrm{SO} 4}$ and $\sim 2.9 \%$ increase in $\delta^{18} \mathrm{O}_{\mathrm{SO} 4}$ across the chemocline is consistent with the process of microbial sulfate reduction; however, the sulfate concentrations also increased in the bottom waters (Figure 4), even when normalized to a conservative element such as chloride. The expected distillation pattern of sulfate consumption and increasing isotope composition of residual sulfate was not observed, and therefore precluded the calculation of fractionation factors using Rayleigh-type equations (e.g., Mariotti et al., 1981).

The $\delta^{34} \mathrm{~S}$ value of dissolved sulfide in the water column was $-14.8 \%$ at the oxic-anoxic interface and decreased to a minimum value of $-25.1 \%$ one meter below the chemocline $(8 \mathrm{~m}$, September 2006, Figure 4). The isotopic composition of dissolved sulfide then increased progressively with depth by $\sim 2 \%$ above the sediment-water interface (12 to $13 \mathrm{~m}$ depth). The average isotopic offset at the chemocline $\left(\Delta^{34} \mathrm{~S}_{\mathrm{SO} 4-\mathrm{H} 2 \mathrm{~S}}=37.1 \%\right.$ ), calculated as the difference between $\delta^{34} \mathrm{~S}_{\mathrm{SO} 4}$ and $\delta^{34} \mathrm{~S}_{\mathrm{H} 2 \mathrm{~S}}$, increased with depth until $7.5 \mathrm{~m}\left(\Delta^{34} \mathrm{~S}_{\mathrm{SO}-\mathrm{H} 2 \mathrm{~S}}=51 \%\right.$, where it maintained a constant offset throughout the lower water column. The apparent fractionations are consistent with previous results of Overmann et al. (1996), which ranged from 49.4 to $55.5 \%$.

\section{Sedimentary sulfur and pore waters in Mahoney Lake}

Solid-phase sulfur concentrations in sediments collected below the euxinic water mass (Cores 2 and 3) were marginally higher than the sulfur content in a core collected above the chemocline (Core 9) (Table 2; Figure 5A). In Cores 2 and 3, AVS averaged $0.26 \pm 0.06$ wt.\% $(\mathrm{n}=29)$, 
412 compared to Core 9 concentrations of $0.12 \pm 0.07$ wt.\% $(n=15)$. Downcore AVS was generally

413 invariant within the anoxic cores relative to the subtle increase in concentrations toward the

414 terminal depth of the oxic core. Pyrite-S concentrations (CRS) were higher in the anoxic cores $415(0.32 \pm 0.2$ wt. $\%, n=19)$ relative to the oxic core $(0.04 \pm 0.01 \mathrm{wt} . \%, \mathrm{n}=14)$. There was a 416 distinct pyrite maximum at $5.5 \mathrm{~cm}$, followed by a near-linear decrease in concentrations within 417 Core 2. The high degree of sulfurization (DOS $>0.7$ ) within Cores 2 and 3 positioned below the 418 monimolimnion, including high values right at the sediment-water interface, is consistent with 419 pyrite that formed in the euxinic water column or at the sediment-water interface (i.e., syngenetic 420 pyrite). Mineral sulfide formation increased with sediment depth in oxic Core 9. Coincident with 421 this increase, the DOS generally increased from a surficial value of 0.62 to 0.88 at the base of the 422 core but with a distinct minimum of 0.28 at $9 \mathrm{~cm}$. The high DOS values in Core 9 suggest past 423 euxinic conditions at this presently oxic site (see discussion below).

425 The concentrations and isotope values of sulfate in pore waters (Table 3) extracted from cores 426 collected above and below the current position of the chemocline reflect the chemical 427 composition of the overlying water. Specifically, interstitial sulfate concentrations in Cores 2 428 and $3(451.6 \pm 27 \mathrm{mM})$ were similar to sulfate levels within the anoxic water column $(426.7 \pm 53$ $429 \mathrm{mM})$. Likewise, within the oxic portion of the lake, Core 9 pore waters $(300.1 \pm 7 \mathrm{mM})$ were 430 similar to those within the mixolimnion $(353.8 \pm 44 \mathrm{mM})$. The isotopic composition of pore 431 water sulfate was nearly identical to the respective $\delta^{34} \mathrm{~S}_{\mathrm{SO} 4}$ and $\delta^{18} \mathrm{O}_{\mathrm{SO} 4}$ of the oxic and anoxic 432 bottom waters (Figure 5B). Although pore water sulfide concentrations were highly variable 433 within Cores 2 and $3(14.63 \pm 7 \mathrm{mM})$, dissolved sulfide levels within Core $9(1.66 \pm 0.4 \mathrm{mM})$ 434 were uniform and an order of magnitude lower than those within the euxinic cores (Table 3). The 
$435 \delta^{34} \mathrm{~S}$ of pore water sulfide from Cores 2 and $3(-22.1 \pm 2 \%$ ) was consistent with that of bottom-

436 water sulfide $(-22.5 \pm 2.8 \%$ ) (Figure $5 \mathrm{~B})$. Relative to the anoxic bottom waters, however, the

437 isotopic composition of dissolved sulfide in Core 9 pore waters tended toward lower $\delta^{34} \mathrm{~S}$ values,

438 ranging from -17.9 to $-36.0 \%$.

\section{4. Discussion}

\section{$441 \quad$ Stable isotope spatial patterns and the Mahoney Lake sulfur supply}

442 The sulfur inventory of Mahoney Lake is exceptionally large, even when compared to both

443 modern and ancient seawater. Water column sulfide (>30 mM) is two orders of magnitude higher

444 than concentrations measured in the deep waters of the Black Sea (Neretin et al., 2003), and the

445 sulfate pool $(>300 \mathrm{mM})$ is tenfold greater than modern seawater. Although the source of sulfur 446 has yet to be directly analyzed, Mahoney Lake sulfate is thought to be derived from the chemical 447 dissolution of alkaline lavas (Northcote \& Hall, 1983) in the western extent of the catchment 448 (Marron Formation, Figure 1). The $\delta^{34} \mathrm{~S}$ for such a source should fall near 0\%o, but intriguingly, 449 the isotopic composition of sulfate in Mahoney Lake $\left(\delta^{34} \mathrm{~S}_{\mathrm{SO} 4} \approx 22 \%\right.$ ) is similar to that of 450 modern seawater $\left(\delta^{34} \mathrm{~S}_{\mathrm{SO} 4}=21 \%\right.$ ) (Rees, 1978). Equivalent values $\left(\delta^{34} \mathrm{~S}_{\mathrm{SO} 4}=19.9 \%\right)$ were 451 reported for drill-hole fluids (Michel et al., 2002) that infiltrate the White Lake Formation 452 (composed of shale, sandstones, and volcanic conglomerates) $5 \mathrm{~km}$ to the northwest of the study 453 area (Church, 2002).

455 The fault beneath both lakes (Figure 1) is a potential pathway for fluid flow into the catchment 456 given that the overall geology of this region is highly fractured and favorable to basin-wide 457 circulation of groundwater and hydrothermal fluids (Michels et al. 2002). Geothermal fluids 
458 common to the region have characteristically high $\delta^{18} \mathrm{O}_{\mathrm{H} 2 \mathrm{O}}$ (Magaritz \& Taylor, 1986; Criss et

459 al., 1991) (Figure 2, inset) and are unlikely sources of fluids because the lake water is very

460 similar to meteoric inputs (Figure 2, LMWL). Long-term monitoring of lake levels further 461 confirm that groundwater inflow is the dominant supply of water into Mahoney Lake (Northcote $462 \&$ Hall, 2000).

463

464 The similarity between $\delta^{34} \mathrm{~S}$ of the greenstone $(0.8 \%$ ) and Sleeping Lake sulfate $(1.6 \%$ ) suggests 465 a sulfur source distinct from Mahoney Lake and Mahoney pond, which are both 20\%o higher and 466 located less than $1 \mathrm{~km}$ away (Figure 1). The high $\delta^{34} \mathrm{~S}_{\mathrm{SO} 4}$ values in Mahoney Lake and the 467 adjacent pond were derived either from a sulfur source from the western extent of the catchment 468 or from a precursor sulfate similar to that of Sleeping Lake but that was heavily overprinted by 469 isotopic fractionation during dissimilatory sulfate reduction. The Mahoney pond, perched above 470 the lake, was observed to vary from a dry salt bed (2006) to a shallow pond (2008) during our 471 two visits. Driving the sulfate pool to higher $\delta^{34} \mathrm{~S}$ and $\delta^{18} \mathrm{O}$ in both an ephemeral pond and a 472 persistent lake would require similar redox conditions and organic matter availability. However, 473 climatic controls in the region suggest that the Mahoney pond likely remained dry for extended 474 periods relative to the more stable water balance of Mahoney Lake. As such, sulfate pools in the 475 two settings would evolve on different timescales and under different conditions, and therefore 476 dissimilar $\delta^{34} \mathrm{~S}$ and $\delta^{18} \mathrm{O}$ values should result. We are left with the likelihood that sulfate-rich 477 waters in Mahoney Lake are delivered from weathering products derived from formations 478 located to the west of the fault that bisects the catchment. 
481 Our study captured the steady-state isotopic variability $\left(\delta^{34} \mathrm{~S}_{\mathrm{SO} 4}, \delta^{18} \mathrm{O}_{\mathrm{SO} 4}\right.$, and $\left.\delta^{34} \mathrm{~S}_{\mathrm{H} 2 \mathrm{~S}}\right)$ of

482 microbial processes within the Mahoney Lake water column during late summer to early fall. A

483 turbidity maximum (Figure 3B) that coincides with the purple layer, the first appearance of

484 dissolved sulfide, and near complete light attenuation, is proxy evidence for increased microbial

485 biomass at the oxic-anoxic interface. The microbial plate (at $7 \mathrm{~m}$ ) absorbs available light almost

486 completely (Figure 3B), thus inhibiting further autotrophic production deeper in the water 487 column.

489 Microbial activity within the plate follows a seasonal pattern marked by peak productivity by 490 purple sulfur bacteria during the late spring through early summer (Overmann et al., 1996).

491 Through concomitant degradation of this biomass, sulfate reduction in the plate also becomes

492 quantitatively important in late spring but extends through early fall (Overmann et al., 1991;

493 Overmann et al., 1996). Primary production by purple sulfur bacteria is most intense at the top of 494 the plate and is regulated by incoming solar radiation and the upward flux of dissolved sulfide 495 transported from the monimolimnion (Overmann et al., 1991; Overmann et al., 1996). Mass 496 balance estimates (Overmann et al., 1994; Overmann et al., 1996) as well as metagenomic data 497 (Hamilton et al., 2014) indicate that chemoautotrophy is a significant sulfide oxidation pathway 498 within the plate - in addition to anoxygenic photosynthesis.

500 Comparison of rates of sulfate reduction (i.e., sulfide production) and anoxygenic photosynthetic 501 productivity suggests that sulfate reduction is carbon-limited (Overmann et al., 1991; Overmann 502 et al., 1996; Hamilton et al., 2014). Measured rates of carbon fixation and heterotrophic activity 503 reveal that the carbon demand by sulfate reducers is greater than the amount of carbon fixed 
504 during the summer; however, annual fixation rates $\left(33.5 \mathrm{~g} \mathrm{C} \mathrm{m}^{-2} \mathrm{yr}^{-1}\right)$ are sufficient to satisfy the 505 demand of sulfate reducers within the microbial plate (22.5 $\left.\mathrm{g} \mathrm{C} \mathrm{m}^{-2} \mathrm{yr}^{-1}\right)$ (Overmann et al., 1996).

506 Details of the extant microbial community were further refined by a recent study of 16s rRNA 507 genes, which demonstrated that the Mahoney sulfur cycle is mediated by phototrophic sulfide 508 oxidizers and oxidation of sulfide and intermediates by Epsilonproteobacteria and 509 Deltaproteobacteria at the chemocline (7m) (Klepac-Ceraj et al., 2012). Microbiological 510 evidence was also observed for sulfate reducers throughout the monimolimnion and within the

511 sediments (Klepac-Ceraj et al., 2012; Hamilton et al., 2014). Although direct measurements of

512 sulfate reduction rates and biomass enumerations are needed to determine the relative roles of 513 these microorganisms, the genetic data confirm the activity of sulfate reducers within the lower 514 water column and the sediments.

516 The co-occurring processes of microbial sulfide production and sulfide oxidation provide a 517 unique opportunity to study sulfur redox chemistry in a highly sulfidic natural system. Isotope 518 patterns of sulfate and sulfide indicate active sulfate reduction at the oxic-anoxic interface in the 519 water column (Figure 4$)$. In our study, rapid increases in $\delta^{34} \mathrm{~S}_{\mathrm{SO} 4}\left(\sim 5 \%\right.$ ) and $\delta^{18} \mathrm{O}_{\mathrm{SO} 4}(\sim 3 \%$ ) 520 stabilized to constant values within the first $0.5 \mathrm{~m}$ below the chemocline. The relatively uniform 521 sulfur isotope values for the sulfide in the deeper monimolimnion also increased at the 522 chemocline by 7 to $9.5 \%$. These isotope patterns are best explained by a combination of 523 fractionations that occur during sulfate reduction and sulfide oxidation.

525 Initial experiments with laboratory cultures suggested that the isotope effect that accompanies 526 dissimilatory sulfate reduction produces offsets between sulfate and sulfide $\left(\Delta^{34} \mathrm{~S}_{\mathrm{SO}-\mathrm{H} 2 \mathrm{~S}}\right)$ of up to 

46\%o (Kaplan \& Rittenberg, 1964b; Chambers et al., 1975) and that these results may reflect the maximum fractionations possible by sulfate reduction alone in the lab or natural settings

529 (Canfield, 2001). However, recent culture experiments (Sim et al., 2011; Leavitt et al., 2013) 530 and work in natural environments (Canfield et al., 2010) demonstrate fractionations of 60-70\%o

531 for sulfate reduction alone. Metabolic models for sulfate uptake followed by a series of 532 enzymatic reduction steps within the cell that reduce sulfite and ultimately excrete sulfide (Rees, 533 1973) may under-predict the magnitude of fractionation found in the natural environment (65-

534 70\%o) (Rudnicki et al., 2001; Wortmann et al., 2001). Brunner and Bernasconi (2005) reassessed 535 biochemical pathways and fractionation effects that accompany reduction of sulfite to sulfide via 536 the trithionate pathway and extended the potential fractionations up to $70 \%$. Network reaction 537 models that incorporated multiple sulfur isotopes $\left({ }^{32} \mathrm{~S},{ }^{33} \mathrm{~S},{ }^{34} \mathrm{~S}\right.$, and ${ }^{36} \mathrm{~S}$ ) (Farquhar et al., 2003; 538 Farquhar et al., 2007; Johnston et al., 2007) improved the ability to model internal sulfur 539 transformations, yet the relevant consequences of the enzyme dissimilatory sulfite reductase, 540 which catalyzes the reduction of sulfite to sulfide, remain to be fully explored and understood 541 (Bradley et al., 2011). The models discussed above establish the theoretical constraints on sulfur 542 isotope effects during sulfate reduction, but the full expression of $\delta^{34} \mathrm{~S}$ fractionation may also 543 reflect environmental variables such as sulfate reduction rates (Kaplan \& Rittenberg, 1964a; 544 Kemp \& Thode, 1968), carbon substrate (Aharon \& Fu, 2000; Bolliger et al., 2001; Detmers et 545 al., 2001), environmental conditions and microbial community structure (Brüchert et al., 2001; 546 Detmers et al., 2001), and the size of the sulfate reservoir (Harrison \& Thode, 1958; Habicht et 547 al., 2002). 
549 The oxidative sulfur cycle may further expand the isotopic difference between sulfate and

550 sulfide. The presence of dissolved oxygen and purple sulfur bacteria at the redox interface of

551 Mahoney Lake promotes abiotically and biotically mediated sulfide oxidation. However, sulfur

552 isotope effects associated with sulfide oxidation are small $( \pm 5 \%$ o). For example, direct chemical

553 oxidation of aqueous sulfide with molecular oxygen can increase $\delta^{34} \mathrm{~S}_{\mathrm{H} 2 \mathrm{~S}}$ by $5 \%$ (Fry et al.,

554 1988b), and purple sulfur bacteria typically produce residual $\delta^{34} \mathrm{~S}_{\mathrm{H} 2 \mathrm{~S}}$ that is 2-5\% lower than the

555 product sulfate (Fry et al., 1984; Fry, 1986; Fry et al., 1988a; Zerkle et al., 2009; Zerkle et al.,

556 2010; Brabec et al., 2012). Much larger fractionations are expected for sulfur disproportionation.

557 For example, the simultaneous oxidation and reduction of sulfite produces ${ }^{34} \mathrm{~S}$-enriched sulfate

558 (7-12\%o) and ${ }^{34}$ S-depleted sulfide (20-37\%o) (Habicht et al., 1998). Combined transformations of

559 reduction, reooxidation, and disproportionation have been invoked to explain large net isotopic

560 offsets between sulfate and sulfide (Canfield \& Thamdrup, 1994), particularly if the redox cycle

561 is repeated multiple times.

562

563 Chemical (Zhang \& Millero, 1994) and microbial (Zopfi et al., 2001) sulfide oxidation at the

564 chemocline generates intermediate sulfur compounds $\left(\mathrm{S}^{0}, \mathrm{SO}_{3}{ }^{2-}, \mathrm{S}_{2} \mathrm{O}_{3}{ }^{2-}\right)$ that can undergo

565 disproportionation; however, biological and environmental conditions in Mahoney Lake

566 potentially preclude or limit disproportionation to a very narrow zone within the uppermost

567 portion of the chemocline. For example, purple sulfur bacteria oxidize sulfide directly to

568 elemental sulfur, producing only very low levels of thiosulfate in Mahoney Lake $(<1-20 \mu \mathrm{M})$

569 - levels that can inhibit thiosulfate disproportionation (Overmann et al., 1996). Furthermore, the

570 high sulfide levels within the monimolimnion, well in excess of the sulfide tolerance $(\sim 1 \mathrm{mM})$

571 for either elemental sulfur or thiosulfate disproportionators (Thamdrup et al., 1993), likely 
572 restricts disproportionators to the upper-cm of the chemocline. That said, the spatial resolution of

573 our sampling methods (10 to $100 \mathrm{~cm})$ might not capture the microbial signatures or specific

574 chemical conditions at the top of the sulfide interface where sulfur disproportionating organisms

575 could be active.

577 The microbial process of sulfate reduction and associated rates appear to be to have the greatest

578 influence on the isotopic patterns observed in this hyper-euxinic lake. The apparent fractionation

579 between sulfate and sulfide (37.1 to $39.5 \%$ ) at the chemocline increased to $51 \%$ o in water layers

580 below the chemocline and remained fairly uniform throughout the monimolimnion (Figure 6).

581 Consistent with previous results from Mahoney that ranged from 49 to $55 \%$ o for coeval sulfate

582 and sulfide sampled at the chemocline and $12 \mathrm{~m}$ water depth (Overmann et al., 1996), our data

583 expand the vertical resolution and capture the increase in $\delta^{34} \mathrm{~S}_{\mathrm{H} 2 \mathrm{~S}}$ values at the chemocline. The

584 isotopic offset between oxidized and reduced sulfur in Mahoney Lake is similar to the large

585 fractionations reported for euxinic marine water columns such as in the Black Sea, Cariaco

586 Basin, Framvaren Fjord, Mariager Fjord, and the Orca Basin (Sweeney \& Kaplan, 1980; Sheu et

587 al., 1988; Fry et al., 1991; Mandernack et al., 2003; Neretin et al., 2003; Sørensen \& Canfield,

588 2004; Li et al., 2010), as well as euxinic lakes such as Lake Cadagno, Crawford Lake, and

589 Fayetteville Green Lake (Deevey et al., 1963; Fry, 1986; Dickman \& Thode, 1990; Canfield et

590 al., 2010; Zerkle et al., 2010). Mahoney Lake has the highest concentrations of dissolved sulfide

591 (>30 mM) and sulfate (> $300 \mathrm{mM})$ among these stratified water bodies. The large, effectively

592 infinite sulfate reservoir in Mahoney Lake would preclude significant reservoir effects during

593 sulfate reduction. When all these observations are considered, our favored interpretation is that

594 large fractionations are dominantly instantaneous, occurring via sulfate reduction alone without 
contributions from disproportionation in the sediment and water column. For these reasons, sulfate reduction exerts the greatest control on $\delta^{34} \mathrm{~S}$ fractionation in Mahoney Lake.

Paired $\delta^{34} \mathrm{~S}_{\mathrm{SO} 4}$ and $\delta^{18} \mathrm{O}_{\mathrm{SO} 4}$ data offer an additional constraint on the microbial redox cycle within Mahoney Lake. The low temperature and near-neutral $\mathrm{pH}$ of the Mahoney water column measured during our studies $\left(\mathrm{pH} 7-9,9-24^{\circ} \mathrm{C}\right.$ ), as well as during long-term monitoring

601 (Northcote \& Halsey, 1969; Northcote \& Hall, 1983), suggest that sulfate-oxygen has not undergone abiotic equilibrium exchange and thus records biogenic oxygen isotope effects. Under anoxic conditions, sulfate-oxygen can fractionate during sulfate reduction, and the extent of 604 enrichment is controlled by kinetic isotope effects imparted during intracellular enzymatic steps and/or equilibrium oxygen exchange with water. Mizutani and Rafter (1969) proposed a 1:4

$606\left(\delta^{18} \mathrm{O}_{\mathrm{SO} 4}: \delta^{34} \mathrm{~S}_{\mathrm{SO} 4}=0.25\right)$ kinetic relationship between the $\delta^{34} \mathrm{~S}$ and $\delta^{18} \mathrm{O}$ of sulfate based on an 607 assumption of preferential ${ }^{16} \mathrm{O}$-bond rupture and the stoichiometry of the sulfate molecule. The 608 theoretical $\delta^{18} \mathrm{O}_{\mathrm{SO} 4}: \delta^{34} \mathrm{~S}_{\mathrm{SO} 4}$ slope of 0.25 suggests the $\delta^{34} \mathrm{~S}$ and $\delta^{18} \mathrm{O}$ of residual sulfate evolves in 609 a linear relationship during sulfate reduction; however, studies of natural samples tend to reveal a curvilinear response that implies equilibrium isotope exchange regulates the oxygen isotope

611 composition of residual sulfate (Böttcher et al., 1998; Brunner et al., 2005; Brunner et al., 2012;

612 Antler et al., 2013). Culturing experiments and reactive transport models of natural samples point

613 to oxygen isotope exchange between water and metabolic intermediates (APS, AMP, and sulfite)

614 that buffers the $\delta^{18} \mathrm{O}_{\mathrm{SO} 4}$ to a maximum value determined by the ambient $\delta^{18} \mathrm{O}_{\mathrm{H} 2 \mathrm{O}}$ value and 615 associated fractionation factors (Mizutani \& Rafter, 1973; Fritz et al., 1989; Brunner et al., 2005;

616 Knöller et al., 2006; Wortmann et al., 2007; Turchyn et al., 2010). The combined effects of 617 Rayleigh-type kinetic isotope fractionations and oxygen isotope exchange during sulfate 
618 reduction thus results in non-linear $\delta^{18} \mathrm{O}-\delta^{34} \mathrm{~S}$ arrays. In studies of marine pore waters, sulfate

619 approaches a plateau in $\delta^{18} \mathrm{O}_{\mathrm{SO} 4}$, in apparent equilibrium with seawater, as $\delta^{34} \mathrm{~S}_{\mathrm{SO} 4}$ evolves

620 toward higher values (Zak et al., 1980; Böttcher et al., 1998; Blake et al., 2006; Riedinger et al.,

621 2010; Wehrmann et al., 2011; Antler et al., 2013). Empirical equations based on high

622 temperature exchange experiments between sulfate and water (Lloyd, 1968; Mizutani, 1972) and

623 quantum mechanical calculations (Zeebe, 2010) can constrain the $\delta^{18} \mathrm{O}_{\mathrm{SO}}$ value in equilibrium

624 with ambient water. These relationships (Lloyd, 1968; Mizutani, 1972; Zeebe, 2010) yield

625 apparent equilibrium $\delta^{18} \mathrm{O}_{\mathrm{SO} 4}$ values ranging between 24 to $36 \%$ o for the temperature and isotopic

626 composition of anoxic water (about $9^{\circ} \mathrm{C}$ and $-2 \%$ ) in Mahoney Lake. These equilibrium values

627 overestimate the observed $\delta^{18} \mathrm{O}_{\mathrm{SO} 4}$ by 3 to $15 \%$.

628

629 Instead, we observe near-linear patterns of $\delta^{18} \mathrm{O}_{\mathrm{SO} 4}$ and $\delta^{34} \mathrm{~S}_{\mathrm{SO} 4}$ in the water columns sampled in

630 fall and summer (Figure 7), which is a trend more consistent with high sulfate reduction rates

631 than equilibrium isotope exchange (Böttcher et al., 1998; Brunner \& Bernasconi, 2005; Brunner

632 et al., 2012; Antler et al., 2013). The model arrays represent a range of possible solutions for the

633 internal cycling of sulfur during microbial sulfate reduction (Figure 7). Steep slopes (Figure 7A,

634 Trend B) with large changes in $\delta^{18} \mathrm{O}_{\mathrm{SO} 4}$ relative to those in $\delta^{34} \mathrm{~S}_{\mathrm{SO} 4}$ are consistent with lower rates

635 of sulfate reduction and enhanced recycling of intracellular sulfur (Antler et al., 2013).

636 Conversely, low-angle slopes (Figure 7A, Trend A) with little change in $\delta^{18} \mathrm{O}_{\mathrm{sO}}$ over large

637 changes in $\delta^{34} \mathrm{~S}_{\mathrm{SO} 4}$ are observed in systems with rapid sulfate reduction rates and minimal

638 recycling of intracellular sulfur (Antler et al., 2013). 
640 In addition to the behavior in $\delta^{18} \mathrm{O}_{\mathrm{SO} 4}-\delta^{34} \mathrm{~S}_{\mathrm{SO} 4}$, the extent of instantaneous fractionation between

641 water column sulfate and sulfide lends support to our interpretation of high sulfate reduction

642 rates in Mahoney Lake. It is well demonstrated that sulfur isotope fractionation factors are

643 inversely proportional to the rates of sulfate reduction (Sim et al., 2011; Leavitt et al., 2013),

644 which is in turn dependent on the availability and reactivity of organic matter (e.g., Overmann,

645 1997; Hamilton et al., 2014). We observed sulfide with high $\delta^{34} \mathrm{~S}(-14.8 \%$ ) and the smallest

646 isotopic offset between sulfate and sulfide (37.1\%o) at the chemocline (Figure 6), which may

647 reflect the rapid rates of sulfate reduction in that portion of the water column. The increase in

$648 \delta^{18} \mathrm{O}_{\mathrm{SO} 4}$ and $\delta^{34} \mathrm{~S}_{\mathrm{SO} 4}$ thus depends on the localized activity of sulfate reducers. The process of

649 microbial sulfate reduction may occur at the redoxcline in the water column, throughout the

650 water column, and possibly in the sediments as well. The anoxic basins of the Black Sea and

651 Cariaco Basin serve as templates for recognizing such hotspots of microbial activity. Sulfate

652 reduction rates measured in the Black Sea revealed distinct zones of sulfate reduction within the

653 chemocline and at the sediment-water interface (Albert et al., 1995). Volumetrically, the rates of

654 sulfate reduction within the sediments of the Black Sea are three-fold greater than those within

655 the water column, suggesting that much of the sulfide in the water column is delivered via 656 diffusion from sulfate reduction in the sediments (Albert et al., 1995). Similar zones and modes

657 of sulfide production are postulated for the Caricaco Basin (Fry et al., 1991; Li et al., 2010). The 658 microbial diversity of Mahoney Lake suggests that sulfate reducing bacteria are distributed 659 throughout the anoxic water column and sediments (Hamilton et al., 2014). The near-linear 660 isotope arrays for sulfate with $\delta^{18} \mathrm{O}_{\mathrm{SO} 4}: \delta^{34} \mathrm{~S}_{\mathrm{SO} 4}$ slopes ranging between 0.47 (July $2008 ; \mathrm{R}^{2}=$ $6610.94)$ and $0.60\left(\right.$ September $\left.2006 ; R^{2}=0.96\right)($ Figure 7$)$ are consistent with high sulfate reduction 662 rates in the water column. 
664 It is intriguing that the slope shifts from low values in the summer (Figure 7C) to higher values

665 in fall (Figure $7 \mathrm{~B}$ ). The shallower $\delta^{18} \mathrm{O}_{\mathrm{SO} 4}: \delta^{34} \mathrm{~S}_{\mathrm{SO} 4}$ slope in the summer implies sulfate reduction 666 rates that are relatively higher than those in the fall. Overmann et al. (1996) observed that sulfate 667 reduction rates peak during the summer after the spring bloom of purple sulfur bacteria, and then 668 decrease in the fall as photosynthetic activity diminishes. Labile organic acids released from the 669 degradation of purple sulfur bacteria provide the primary carbon substrate mineralized by sulfate 670 reducers (Overmann et al., 1996). Previous studies demonstrate that linear $\delta^{18} \mathrm{O}_{\mathrm{SO} 4}: \delta^{34} \mathrm{~S}_{\mathrm{SO} 4}$ slopes

671 are sensitive to the quantity and reactivity of organic matter mineralized during sulfate reduction

672 (Aharon \& Fu, 2000; Antler et al., 2014). The change in the $\delta^{18} \mathrm{O}_{\mathrm{SO} 4}: \delta^{34} \mathrm{~S}_{\mathrm{SO} 4}$ slope of residual

673 sulfate reported here thus may track the seasonal activity of sulfate reduction stimulated by the

674 localized primary productivity of anoxygenic phototrophs within the plate. Dedicated seasonal

675 sampling may capture a more robust isotopic signature of evolving sulfate reduction rates.

676 Likewise, our modeled data could be re-evaluated as separate but coupled trajectories for the

677 chemocline and deeper sulfide production within the bottom waters and surficial sediments;

678 however, the current data set lacks the spatial resolution to make this determination. The 679 potentially distinct zones and rates of reduction might be revealed within higher resolution $680 \quad \delta^{18} \mathrm{O}_{\mathrm{SO} 4}$ and $\delta^{34} \mathrm{~S}_{\mathrm{SO} 4}$ data collected at the sub-cm scale.

682 Close inspection of the isotope variability near the chemocline does reveal that $\delta^{18} \mathrm{O}_{\mathrm{SO} 4}$ varies 683 more than $\delta^{34} \mathrm{~S}_{\mathrm{SO} 4}$ (Figure $7 \mathrm{~A}$ ). The $2-3 \%$ increase in $\delta^{18} \mathrm{O}_{\mathrm{SO} 4}$ and lack of response in $\delta^{34} \mathrm{~S}_{\mathrm{SO} 4}$ 684 implies sulfate reduction and near quantitative reoxidation to sulfate (i.e., no net sulfur isotope 685 fractionation). Oxygen isotope fraction during disproportionation can be large (up to 21\%o) 
686 (Böttcher et al., 2001) and therefore do not agree with the smaller isotope effects observed here,

687 consistent with our earlier arguments against appreciable disproportionation. Below $7 \mathrm{~m}$ water

688 depth, both $\delta^{18} \mathrm{O}_{\mathrm{SO} 4}$ and $\delta^{34} \mathrm{~S}_{\mathrm{SO} 4}$ follow a sulfate reduction trend of increasing values. Therefore,

689 although there is clear evidence for robust activity of sulfur oxidizing bacteria, the prevailing

690 process of microbial sulfate reduction masks the isotopic fingerprint.

691

692 We acknowledge that thermodynamic equilibrium can achieve large isotopic offsets $(\sim 75 \%$ o $)$

693 between sulfate and sulfide (Ohmoto \& Lasaga, 1982; Chu et al., 2004; Farquhar et al., 2007;

694 Johnston et al., 2007; Leavitt et al., 2014) in the absence of biological activity. The extremely

695 high concentrations of aqueous sulfur compounds (including sulfate, sulfide, and polysulfide)

696 within our study area makes Mahoney Lake a candidate system for the consideration of abiotic

697 isotope fractionation. Equilibrium isotope exchange between sulfate-sulfide depends upon pH

698 and temperature and can equilibrate within days under acidic conditions $(\mathrm{pH}=2)$ and high

699 temperature $\left(>300^{\circ} \mathrm{C}\right) \quad($ Ohmoto \& Lasaga, 1982). However, at normal Earth surface

700 temperatures $\left(25^{\circ} \mathrm{C}\right)$ and neutral $\mathrm{pH}$, near quantitative exchange $(90 \%)$ between aqueous sulfate

701 and sulfide is exceedingly slow, taking on the order of $10^{9}$ years (Ohmoto \& Lasaga, 1982),

702 which is well in excess of the age of Mahoney Lake $\left(10^{4}\right.$ years $)$. The proposed mechanism for

703 sulfate-sulfide exchange may occur through a transient thiosulfate intermediate (Ohmoto \&

704 Lasaga, 1982) or polysulfides (Chu et al., 2004); however, controlled experiments needed to

705 further constrain these processes remain to be conducted. One recent study shows that sulfur

706 isotope exchange may be possible during thiosulfate disproportionation but mass balance

707 considerations suggest that the isotope effects are kinetic (Leavitt et al., 2014). Based on the 
708

709

710

\section{1}

712

713

714

715

716

717

718

719

720

721

722

723

724

725

726

727

728

729

730

current understanding of the sulfate-sulfide system, the isotope offsets in Mahoney Lake are thus most consistent with biologically meditated sulfur cycling.

\section{Linking the pelagic $S$ cycle with the sedimentary record}

The large size of the sulfate and sulfide reservoir defines the isotopic composition of the pore waters within both the oxygenated (Core 9) and the anoxic (Cores 2 and 3) portions of the lake. Pore water $\delta^{34} \mathrm{~S}_{\mathrm{SO} 4}$ and $\delta^{18} \mathrm{O}_{\mathrm{SO} 4}$ values are identical to the isotopic compositions of sulfate from the mixolimnion or the monimoliniom (Figure 5B). Relative to Core 9 collected from the oxic margin of Mahoney Lake, pore waters in Cores 2 and 3 are ${ }^{34} \mathrm{~S}$ - and ${ }^{18} \mathrm{O}$-enriched. The comparatively higher $\delta^{34} \mathrm{~S}_{\mathrm{SO} 4}$ and $\delta^{18} \mathrm{O}_{\mathrm{SO} 4}$ are likely driven by fractionations during sulfate reduction.

$\delta^{34} \mathrm{~S}_{\mathrm{SO} 4}$ data for the water column and associated pore waters plot along mixing trajectories specific to the oxic and anoxic study sites (Figure 8A). Sulfate in the oxic water column has uniform $\delta^{34} \mathrm{~S}_{\mathrm{SO} 4}$ over a broad range of sulfate concentrations. Core 9 pore waters have $\delta^{34} \mathrm{~S}_{\mathrm{SO} 4}$ values identical to those of the mixolimnion. Sulfate in the anoxic water column becomes ${ }^{34} \mathrm{~S}$ enriched as sulfate concentrations increase with depth. Pore waters all have high sulfate concentrations with high $\delta^{34} \mathrm{~S}$ values. Mixing patterns in $\delta^{18} \mathrm{O}_{\mathrm{SO} 4}$ (Figure 8B) show similar trends, albeit with greater scatter in the isotope data. Although the sulfate concentrations within the pore waters remain high and the sulfate isotope data follow patterns of mixing, the pore water $\delta^{34} \mathrm{~S}_{\mathrm{H} 2 \mathrm{~S}}$ values in the oxic margin (Core 9) are highly variable (Figure 6) and decrease depth (Figure 5B), indicating active sulfide production within the sediments. As discussed above, the activity of sulfate reduction within the plate appears be tied to the productivity of purple sulfur 
731 bacteria, this relationship does not preclude the burial of reactive organic compounds that

732 escaped oxidation in the water column.

734 The dissolved sulfide pool is also large within the monimolimnion and the pore waters within

735 Cores 2 and 3. Similarity between $\delta^{34} \mathrm{~S}_{\mathrm{H} 2 \mathrm{~S}}$ in the water column and the pore waters suggests that

736 isotopic compositions are buffered by the large sulfide concentrations within the euxinic water

737 mass (Figure 5B). The concentrations of sedimentary dissolved sulfide, AVS, and pyrite beneath

738 the euxinic waters are appreciable relative to those in the sediments of the oxic margin. The $\delta^{34} \mathrm{~S}$

739 of pyrite, within our small errors, is the same as the composition of water column sulfide (Figure

740 5A). High DOS values ( 0.8) within Cores 2 and 3 suggest water column pyrite synthesis within

741 a euxinic water column. Although the data suggest that pyrite formation is ultimately Fe limited,

742 the high DOS values also suggest that an iron enrichment mechanism perhaps like that observed

743 in the modern Black Sea (e.g., Lyons \& Severmann, 2006) may be operating in the lake.

745 Seasonal recycling by reductive dissolution and oxidation may transport iron into the deeper lake

746 from the oxic margin; however, a benthic shallow-to-deep iron flux at the small scale of this

747 basin has yet to be described elsewhere. The low and invariant $\delta^{34} \mathrm{~S}$ of pyrite within both anoxic

748 cores further supports our interpretation of water column pyrite formation (Lyons, 1997; Lyons

749 et al., 2003). In contrast, pore water sulfide in Core 9 becomes more ${ }^{34} \mathrm{~S}$-depleted with depth, and

750 AVS accumulates with depth, implying sulfide generation in the sediments. The DOS values

751 within the upper $15 \mathrm{~cm}$ of the sediment column also increase down core, consistent with

752 diagenetic pyrite formation, and eventually reach high values more typical of water-column

753 pyrite formation in the euxinic part of the basin (0.8). A shoaling of the chemocline when water 
754 levels were higher likely explains the down-core transition to higher DOS in the now oxic core.

755 Modern observations show the lake experiences long-term volumetric changes. Lake level has

756 dropped more than 5 m since 1961 (Northcote \& Hall, 1990; Northcote \& Hall, 2000; Northcote

$757 \&$ Hall, 2010). Decadal fluctuations in lake height potentially control the vertical position of the

758 chemocline and thus the expansion (when lake levels are high) or contraction (when lake levels

759 are low) of the volume of the euxinic bottom waters. The lateral displacement of the chemocline

760 from depo-center to margin, as tracked by excursions in DOS, may coincide with regional

761 drought. Shoaling events are well documented for the Black Sea (Lyons et al., 1993) and, in

762 Mahoney, are likely caused by changing lake volume.

763

764 Long-term stability of the chemocline

765 The dissolved sulfide concentrations of $>30 \mathrm{mM}$ are considerable and represent extreme euxinic

766 conditions. Very high sulfide concentrations within the anoxic bottom waters are consistent with

767 previous reports (Northcote \& Halsey, 1969; Northcote \& Hall, 1983); however, we also

768 detected free sulfide at isolated depths in the mixolimnion at concentrations ranging 3 to $62 \mu \mathrm{M}$

769 (Table 1, Figure 3). The low but analytically detectable sulfide levels $(>2 \mu \mathrm{M})$ may reflect

770 sulfide released from aggregates of purple sulfur bacteria transported into the oxic surface waters

771 by wind-blown mixing. During both field trips, we observed aggregates of purple sulfur bacteria

772 floating within the mixolimnion and deposited along the shoreline. Overmann et al. (1994)

773 reported that the majority of purple sulfur bacteria were photosynthetically inactive during late

774 summer, and approximately $86 \%$ of the biomass was dispersed from the plate into the upper

775 water column. 
777 Redox instability is part of the history of Mahoney Lake. Paleoreconstructions suggest anoxic

778 conditions commenced with the formation of Mahoney Lake following glacial retreat 11,000

779 years ago. Diatom and midge sediment archives record elevated salinities $(\sim 10 \mathrm{~g} / \mathrm{L})$ throughout

780 much of the Holocene (Heinrichs et al., 1997) and imply that aridity is a persistent feature of the

781 regional climate. Okenone abundances indicate several purple sulfur bacteria blooms and periods

782 of meromixis lasting approximately 1000 years (Overmann et al., 1993; Coolen \& Overmann,

783 1998). The periodicity found in purple sulfur biomarkers is consistent with the absence of

784 laminations during low stands and implies that wind-driven mixing destabilized the stratification

785 (Dickman, 1985; Lowe et al., 1997).

\section{5. Conclusions}

788 We studied the isotope composition of sulfate and sulfide within the water column and sediments 789 of a hyper-euxinic lake. Our analysis of surface water samples collected from four lakes located 790 within the same catchment indicates that the sulfate in Mahoney Lake is derived from rock units 791 in the western portion of the watershed. The sulfate $(>300 \mathrm{mM})$ and sulfide $(>30 \mathrm{mM})$ 792 concentrations in the Mahoney Lake water column are extremely high and unlike sulfur 793 inventories postulated for the Proterozoic and Archean oceans; however, the sulfide availability

794 within the photic zone coupled within a highly active microbial community of sulfate reducing 795 and sulfur phototrophic bacteria provide an ideal natural laboratory for studying biological 796 processes thought to be prevalent in euxinic seas. Our data revealed that although there is clearly 797 a very active plate of purple sulfur bacteria, the associated isotopic biosignature is completely 798 overprinted by the relatively large sulfur and oxygen isotope fractionations associated with 799 sulfate reducing bacteria. The seasonal $\delta^{18} \mathrm{O}_{\mathrm{SO} 4}-\delta^{34} \mathrm{~S}_{\mathrm{SO} 4}$ patterns observed in water column 
800 suggest that sulfate reduction rates (low $\delta^{18} \mathrm{O}_{\mathrm{SO} 4}: \delta^{34} \mathrm{~S}_{\mathrm{SO} 4}$ slope) are high during the summer and

801 decrease in the fall (high $\delta^{18} \mathrm{O}_{\mathrm{SO} 4}: \delta^{34} \mathrm{~S}_{\mathrm{SO} 4}$ slope). The decrease in the offset between sulfate and

802 sulfide $\left(\Delta^{34} \mathrm{~S}_{\mathrm{SO} 4-\mathrm{H} 2 \mathrm{~S}}=37 \%\right)$ near the chemocline is also consistent with higher rates of sulfate

803 reduction (and an associated decrease in fractionation at higher rates). Previous studies

804 demonstrate that productivity of sulfate reducers is dependent upon carbon inputs from purple

805 sulfur bacteria. Although the isotope signatures of sulfate reduction mask the relatively small

806 isotope effects produced during sulfide oxidation, the linear correlation between $\delta^{18} \mathrm{O}_{\mathrm{SO} 4}$ and

$807 \delta^{34} \mathrm{~S}_{\mathrm{SO} 4}$ is potentially influenced by the primary production of anoxygenic photosynthetic

808 bacteria. As with the water column, the $\delta^{34} \mathrm{~S}$ of sedimentary pyrite reflects the process of sulfate

809 reduction. Estimates of the degree of sulfurization (DOS > 0.7) suggest that the deep basin

810 sediments pyrites likely form in the water column and settle to the sediments. Although a

811 mechanism for reactive iron delivery within a small basin such as Mahoney Lake has yet to be

812 fully explored, the trend toward higher DOS within sediments collected from the oxic margin

813 suggests lake level (and water availability) influences the expansion/contraction of the euxinic

814 water mass.

815

816 As a result of strong overprinting by microbial sulfate reduction, there is not an obvious stable

817 isotope signature for photosynthetic sulfide oxidation in Mahoney Lake that could be

818 incorporated into the sedimentary record. In effect, the isotopic expression of sulfate reduction

819 integrated over the entire anoxic water column and under non-sulfate-limiting conditions masks

820 the isotopic effects of phototrophic sulfide oxidation within the $\delta^{18} \mathrm{O}_{\mathrm{SO} 4}-\delta^{34} \mathrm{~S}_{\mathrm{SO} 4}$ system.

821 However, there is clear evidence within seasonal response of $\delta^{18} \mathrm{O}_{\mathrm{SO} 4}-\delta^{34} \mathrm{~S}_{\mathrm{SO} 4}$ for extensive sulfur 822 cycling through phototrophic sulfide oxidation in Mahoney Lake, suggesting that if the difficult 
823 task of constraining ambient $\delta^{18} \mathrm{O}_{\mathrm{H} 2 \mathrm{O}}$ (Brabec et al., 2012) can be surmounted (through, for

824 example, combined clumped isotope paleothermometry and $\delta^{18} \mathrm{O}$ analysis of carbonate phases)

825 the combined sulfur and oxygen isotope systematics of sedimentary sulfate may ultimately 826 provide an archive of the prevalence and magnitude of photosynthetic sulfur cycling during 827 Earth's history.

\section{Acknowledgements}

830 We thank BC Ministry of Environment Area Supervisors R. Gunoff and M. Weston for access to

831 Mahoney Lake and their generous field support. S. Bates, A. Chappaz, A. Dekas, G. Druschel,

832 D. Fike, B. Gill, J. Glass, M. McKibben, N. Planavsky, N. Riedinger, and A. Vossmeyer assisted

833 in the field or laboratory. Hydrolabs were provided by M. Anderson UCR, and LacCore

834 (National Lacustrine Core Facility, Department of Geology and Geophysics, University of 835 Minnesota-Twin Cities). The manuscript benefited from helpful discussions with K. Hall, T.

836 Northcote, C. Alpers, K. Mandernack, and J. Overmann. We also thank D. Johnston and two 837 anonymous reviewers for their thoughtful and constructive reviews. Funding for our research 838 was provided by NASA Exobiology and the NASA Astrobiology Institute (TL), the American 839 Chemical Society Petroleum Research Fund (48736-ND2 to TL and WPG), and an Agouron 840 Institute Geobiology Fellowship (WPG).

\section{References}

844 Aharon P, Fu B (2000) Microbial sulfate reduction rates and sulfur and oxygen isotope fractionations at oil and gas seeps in deepwater Gulf of Mexico. Geochimica et Cosmochimica Acta, 64, 233-246. 
Albert DB, Taylor C, Martens CS (1995) Sulfate reduction rates and low molecular weight fatty acid concentrations in the water column and surficial sediments of the Black Sea. Deep Sea Research Part I: Oceanographic Research Papers, 42, 1239-1260.

Antler G, Turchyn AV, Herut B, Davies A, Rennie VC, Sivan O (2014) Sulfur and oxygen isotope tracing of sulfate driven anaerobic methane oxidation in estuarine sediments. Estuarine, Coastal and Shelf Science, 142, 4-11.

Antler G, Turchyn AV, Rennie V, Herut B, Sivan O (2013) Coupled sulfur and oxygen isotope insight into bacterial sulfate reduction in the natural environment. Geochimica et Cosmochimica Acta, 118, 98-117.

Balci N, Mayer B, Shanks Iii WC, Mandernack KW (2012) Oxygen and sulfur isotope systematics of sulfate produced during abiotic and bacterial oxidation of sphalerite and elemental sulfur. Geochimica et Cosmochimica Acta, 77, 335-351.

Balci N, Shanks WC, Iii, Mayer B, Mandernack KW (2007) Oxygen and sulfur isotope systematics of sulfate produced by bacterial and abiotic oxidation of pyrite. Geochimica et Cosmochimica Acta, 71, 3796-3811.

Bekker A, Holland HD, Wang PL, Rumble D, Stein HJ, Hannah JL, Coetzee LL, Beukes NJ (2004) Dating the rise of atmospheric oxygen. Nature, 427, 117-120.

Berner RA (1970) Sedimentary pyrite formation. Am J Sci, 268, 1-23.

Blake RE, Surkov AV, Böttcher ME, Ferdelman TG, Jørgensen BB (2006) Oxygen isotope composition of dissolved sulfate in deep-sea sediments: eastern equatorial Pacific Ocean. In: Proceedings of the Ocean Drilling Program, Scientific Results (eds Jørgensen BB, D'hondt SL, Miller DJ), pp. 1-23.

Boesen C, Postma D (1988) Pyrite formation in anoxic environments of the Baltic. Am J Sci, 288, 575-603.

Bolliger C, Schroth MH, Bernasconi SM, Kleikemper J, Zeyer J (2001) Sulfur isotope fractionation during microbial sulfate reduction by toluene-degrading bacteria. Geochimica et Cosmochimica Acta, 65, 3289-3298.

Böttcher ME, Oelschläger B, Höpner T, Brumsack H-J, Rullkötter J (1998) Sulfate reduction related to the early diagenetic degradation of organic matter and "black spot" formation in tidal sandflats of the German Wadden Sea (southern North Sea): stable isotope (13C, 34S, 180) and other geochemical results. Organic Geochemistry, 29, 1517-1530.

Böttcher ME, Thamdrup B, Vennemann TW (2001) Oxygen and sulfur isotope fractionation during anaerobic bacterial disproportionation of elemental sulfur. Geochimica et Cosmochimica Acta, 65, 1601-1609.

Bottrell SH, Newton RJ (2006) Reconstruction of changes in global sulfur cycling from marine sulfate isotopes. Earth-Science Reviews, 75, 59-83.

Brabec MY, Lyons TW, Mandernack KW (2012) Oxygen and Sulfur Isotope Fractionation during Sulfide Oxidation by Anoxygenic Phototrophic Bacteria. Geochimica et Cosmochimica Acta, 83, 234-251.

Bradley AS, Leavitt WD, Johnston DT (2011) Revisiting the dissimilatory sulfate reduction pathway. Geobiology, 9, 446-457.

Brocks JJ, Love GD, Summons RE, Knoll AH, Logan GA, Bowden SA (2005) Biomarker evidence for green and purple sulphur bacteria in a stratified Palaeoproterozoic sea. Nature, 437, 866-870. 
Brocks JJ, Schaeffer P (2008) Okenane, a biomarker for purple sulfur bacteria (Chromatiaceae), and other new carotenoid derivatives from the 1640 Ma Barney Creek Formation. Geochimica et Cosmochimica Acta, 72, 1396-1414.

Brüchert V, Knoblauch C, Jørgensen BB (2001) Controls on stable sulfur isotope fractionation during bacterial sulfate reduction in Arctic sediments. Geochimica et Cosmochimica Acta, 65, 763-776.

Brunner B, Bernasconi SM (2005) A revised isotope fractionation model for dissimilatory sulfate reduction in sulfate reducing bacteria. Geochimica et Cosmochimica Acta, 69, 47594771.

Brunner B, Bernasconi SM, Kleikemper J, Schroth MH (2005) A model for oxygen and sulfur isotope fractionation in sulfate during bacterial sulfate reduction processes. Geochimica et Cosmochimica Acta, 69, 4773-4785.

Brunner B, Einsiedl F, Arnold GL, Müller I, Templer S, Bernasconi SM (2012) The reversibility of dissimilatory sulphate reduction and the cell-internal multi-step reduction of sulphite to sulphide: insights from the oxygen isotope composition of sulphate. Isotopes in environmental and health studies, 48, 33-54.

Calmels D, Gaillardet J, Brenot A, France-Lanord C (2007) Sustained sulfide oxidation by physical erosion processes in the Mackenzie River basin: Climatic perspectives. Geology, 35, 1003-1006.

Canfield DE (1998) A new model for Proterozoic ocean chemistry. Nature, 396, 450-453.

Canfield DE (2001) Biogeochemistry of Sulfur Isotopes. In: Stable Isotope Geochemistry (eds Valley JW, Cole DR). Mineralogical Society of America, Washington DC, pp. 607-636.

Canfield DE, Farquhar J (2009) Animal evolution, bioturbation, and the sulfate concentration of the oceans. Proceedings of the National Academy of Sciences, 106, 8123-8127.

Canfield DE, Farquhar J, Zerkle AL (2010) High isotope fractionations during sulfate reduction in a low-sulfate euxinic ocean analog. Geology, 38, 415-418.

Canfield DE, Raiswell R, Westrich JT, Reaves CM, Berner RA (1986) The use of chromium reduction in the analysis of reduced inorganic sulfur in sediments and shales. Chemical Geology, 54, 149-155.

Canfield DE, Teske A (1996) Late Proterozoic rise in atmospheric oxygen concentration inferred from phylogenetic and sulphur-isotope studies. Nature 382, 127-132.

Canfield DE, Thamdrup B (1994) The Production of ${ }^{34}$ S-Depleted Sulfide During Baterial Disproportionation of Elemental Sulfur. Science, 266, 1973-1975.

Chambers LA, Trudinger PA, Smith JW, Burns MS (1975) Fractionation of sulfur isotopes by continuous cultures of Desulfovibrio desulfuricans. Canadian Journal of Microbiology, 21, 1602-1607.

Chanton J, Martens C (1985) The effects of heat and stannous chloride addition on the active distillation of acid volatile sulfide from pyrite-rich marine sediment samples. Biogeochemistry, 1, 375-382-382.

Chiba H, Sakai H (1985) Oxygen isotope exchange rate between dissolved sulfate and water at hydrothermal temperatures. Geochimica et Cosmochimica Acta, 49, 993-1000.

Chu X, Ohmoto H, Cole DR (2004) Kinetics of sulfur isotope exchange between aqueous sulfide and thiosulfate involving intra-and intermolecular reactions at hydrothermal conditions. Chemical Geology, 211, 217-235.

Church BN (2002) Geoscience Map 2002-5: Geology of the Penticton Tertiary Outlier, British Columbia (NTS 082E/5). 
974

975

976

977

978

979

980

981

Claypool GE, Holser WT, Kaplan IR, Sakai H, Zak I (1980) The age curves of sulfur and oxygen isotopes in marine sulfate and their mutual interpretation. Chemical Geology, 28, 199260.

Cline JD (1969) Spectrophotometric Determination of Hydrogen Sulfide in Natural Waters. Limnology and Oceanography, 14, 454-458.

Coolen MJL, Overmann J (1998) Analysis of Subfossil Molecular Remains of Purple Sulfur Bacteria in a Lake Sediment. Applied and Environmental Microbiology, 64, 4513-4521.

Cornwell JC, Morse JW (1987) The characterization of iron sulfide minerals in anoxic marine sediments. Marine Chemistry, 22, 193-206.

Criss RE, Fleck RJ, Taylor HP (1991) Tertiary Meteoric Hydrothermal Systems and their Relation to Ore Deposition, Northwestern United States and Southern British Columbia. Journal of Geophysical Research, 96, 13,335-313,356.

Crowe SA, Paris G, Katsev S, Jones C, Kim S-T, Zerkle AL, Nomosatryo S, Fowle DA, Adkins JF, Sessions AL, Farquhar J, Canfield DE (2014) Sulfate was a trace constituent of Archean seawater. Science, 346, 735-739.

Deevey ES, Nakai N, Stuiver M (1963) Fractionation of Sulfur and Carbon Isotopes in a Meromictic Lake. Science, 139, 407-407.

Detmers J, Bruchert V, Habicht KS, Kuever J (2001) Diversity of Sulfur Isotope Fractionations by Sulfate-Reducing Prokaryotes. Appl. Environ. Microbiol., 67, 888-894.

Dickman M (1985) Seasonal succession and microlamina formation in a meromictic lake displaying varved sediments. Sedimentology, 32, 109-118.

Dickman MD, Thode HG (1990) Sulfur bacteria and sulfur isotope fractionation in a meromictic lake near Toronto, Canada. In: Facets of modern biogeochemistry (eds Ihebhot V, Kempe S, Michaelis W, Spitzg A). Springer-Verlag, pp. 225-241.

Farquhar J, Bao H, Thiemens M (2000) Atmospheric Influence of Earth's Earliest Sulfur Cycle. Science, 289, 756-758.

Farquhar J, Johnston DT, Wing BA (2007) Implications of conservation of mass effects on massdependent isotope fractionations: Influence of network structure on sulfur isotope phase space of dissimilatory sulfate reduction. Geochimica et Cosmochimica Acta, 71, 58625875 .

Farquhar J, Johnston DT, Wing BA, Habicht KS, Canfield DE, Airieau S, Thiemens MH (2003) Multiple sulphur isotopic interpretations of biosynthetic pathways: implications for biological signatures in the sulphur isotope record. Geobiology, 1, 27-36.

Fike DA, Grotzinger JP, Pratt LM, Summons RE (2006) Oxidation of the Ediacaran Ocean. Nature, 444, 744-747.

Fisher MM, Brenner M, Reddy KR (1992) A simple, inexpensive piston corer for collecting undisturbed sediment/water interface profiles. Journal of Paleolimnology, 7, 157-161161.

Fritz P, Basharmal GM, Drimmie RJ, Ibsen J, Qureshi RM (1989) Oxygen isotope exchange between sulphate and water during bacterial reduction of sulphate. Chemical Geology, 79, 99-105.

Fry B (1986) Sources of Carbon and Sulfur Nutrition for Consumers in Three Meromictic Lakes of New York State. Limnology and Oceanography, 31, 79-88.

Fry B, Cox J, Gest H, Hayes JM (1986) Discrimination between ${ }^{34} \mathrm{~S}$ and ${ }^{32} \mathrm{~S}$ during Bacterial Metabolism of Inorganic Sulfur Compounds. Journal of Bacteriology, 165, 328-330. 
982

983

984

985

986

987

988

989

990

991

992

993

994

995

996

997

998

999

1000

1001

1002

1003

1004

1005

1006

1007

1008

1009

1010

1011

1012

1013

1014

1015

1016

1017

1018

1019

1020

1021

1022

1023

1024

1025

1026
Fry B, Gest H, Hayes JM (1984) Isotope effects associated with the anaerobic oxidation of sulfide by the purple photosynthetic bacterium, Chromatium vinosum. FEMS Microbiology Letters, 22, 283-287.

Fry B, Gest H, Hayes JM (1988a) ${ }^{34} \mathrm{~S} /{ }^{32} \mathrm{~S}$ fractionation in sulfur cycles catalyzed by anaerobic bacteria. Appl. Environ. Microbiol., 54, 250-256.

Fry B, Jannasch HW, Molyneaux SJ, Wirsen CO, Muramoto JA, King S (1991) Stable isotope studies of the carbon, nitrogen and sulfur cycles in the Black Sea and Cariaco Trench. Deep Sea Research, 38, S1003-S1019.

Fry B, Ruf W, Gest H, Hayes JM (1988b) Sulfur Isotope Effects Associated with Oxidation of Sulfide by $\mathrm{O}_{2}$ in Aqueous Solution. Chemical Geology, 73, 205-210.

Gibson JJ, Edwards TWD, Birks SJ, St Amour NA, Buhay WM, Mceachern P, Wolfe BB, Peters DL (2005) Progress in isotope tracer hydrology in Canada. Hydrological Processes, 19, 303-327.

Gibson JJ, Prepas EE, Mceachern P (2002) Quantitative comparison of lake throughflow, residency, and catchment runoff using stable isotopes: modelling and results from a regional survey of Boreal lakes. Journal of Hydrology, 262, 128-144.

Habicht KS, Canfield DE, Rethmeier J (1998) Sulfur isotope fractionation during bacterial reduction and disproportionation of thiosulfate and sulfite. Geochimica et Cosmochimica Acta, 62, 2585-2595.

Habicht KS, Gade M, Thamdrup B, Berg P, Canfield DE (2002) Calibration of Sulfate Levels in the Archean Ocean. Science, 298, 2372-2374.

Hamilton T, Bovee R, Thiel V, Sattin S, Mohr W, Schaperdoth I, Vogl K, Gilhooly W, Lyons T, Tomsho L (2014) Coupled reductive and oxidative sulfur cycling in the phototrophic plate of a meromictic lake. Geobiology, 12, 451-468.

Harrison AG, Thode HG (1958) Mechanisms of the bacterial reduction of sulphate from isotope fractionation studies. Transactions of the Faraday Society, 54, 85-92.

Heinrichs M, Wilson S, Walker I, Smol J, Mathewes R, Hall K (1997) Midge-and diatom-based palaeosalinity reconstructions for Mahoney Lake, Okanagan Valley, British Columbia, Canada. International Journal of Salt Lake Research, 6, 249-267.

Hoering TC, Kennedy JW (1957) The Exchange of Oxygen between Sulfuric Acid and Water1. Journal of the American Chemical Society, 79, 56-60.

Holser WT, Kaplan IR, Sakai H, Zak I (1979) Isotope geochemistry of oxygen in the sedimentary sulfate cycle. Chemical Geology, 25, 1-17.

Hurtgen MT, Arthur MA, Halverson GP (2005) Neoproterozoic sulfur isotopes, the evolution of microbial sulfur species, and the burial efficiency of sulfide as sedimentary pyrite. Geology, 33, 41-44.

Johnston DT, Farquhar J, Canfield DE (2007) Sulfur isotope insights into microbial sulfate reduction: When microbes meet models. Geochimica et Cosmochimica Acta, 71, 39293947.

Johnston DT, Wing BA, Farquhar J, Kaufman AJ, Strauss H, Lyons TW, Kah LC, Canfield DE (2005) Active Microbial Sulfur Disproportionation in the Mesoproterozoic. Science, 310, 1477-1479.

Johnston DT, Wolfe-Simon F, Pearson A, Knoll AH (2009) Anoxygenic photosynthesis modulated Proterozoic oxygen and sustained Earth's middle age. Proceedings of the National Academy of Sciences, 106, 16925-16929. 
1027

1028

1029

1030

1031

1032

1033

1034

1035

1036

1037

1038

1039

1040

1041

1042

1043

1044

1045

1046

1047

1048

1049

1050

1051

1052

1053

1054

1055

1056

1057

1058

1059

1060

1061

1062

1063

1064

1065

1066

1067

1068

1069

1070

1071
Kaplan IR, Rittenberg SC (1964a) Microbiological Fractionation of Sulphur Isotopes. Journal of General Microbiology, 34, 195-212.

Kaplan IR, Rittenberg SC (1964b) Microbiological Fractionation of Sulphur Isotopes. Microbiology, 34, 195-212.

Kemp ALW, Thode HG (1968) The mechanism of the bacterial reduction of sulphate and of sulphite from isotope fractionation studies. Geochimica et Cosmochimica Acta, 32, 7191.

Klepac-Ceraj V, Hayes CA, Gilhooly WP, Lyons TW, Kolter R, Pearson A (2012) Microbial diversity under extreme euxinia: Mahoney Lake, Canada. Geobiology, 10, 223-235.

Knöller K, Vogt C, Richnow H-H, Weise S (2006) Sulfur and Oxygen Isotope Fractionation during Benzene, Toluene, Ethyl Benzene, and Xylene Degradation by Sulfate-Reducing Bacteria. Environmental Science and Technology, 40, 3879-3885.

Leavitt WD, Cummins R, Schmidt ML, Sim MS, Ono S, Bradley AS, Johnston DT (2014) Multiple sulfur isotope signatures of sulfite and thiosulfate reduction by the model dissimilatory sulfate-reducer, Desulfovibrio alaskensis str. G20. Frontiers in microbiology, 5.

Leavitt WD, Halevy I, Bradley AS, Johnston DT (2013) Influence of sulfate reduction rates on the Phanerozoic sulfur isotope record. Proceedings of the National Academy of Sciences, 110, 11244-11249.

Lewis T (1984) Geothermal energy from Penticton Tertiary outlier, British Columbia: an initial assessment. Canadian Journal of Earth Sciences, 21, 181-188.

Li X, Gilhooly Iii WP, Zerkle AL, Lyons TW, Farquhar J, Werne JP, Varela R, Scranton MI (2010) Stable sulfur isotopes in the water column of the Cariaco Basin. Geochimica et Cosmochimica Acta, 74, 6764-6778.

Lloyd RM (1968) Oxygen Isotope Behavior in the Sulfate-Water System. Journal of Geophysical Research, 73, 6099.

Lowe DJ, Green JD, Northcote TG, Hall KJ (1997) Holocene Fluctuations of a Meromictic Lake in Southern British Columbia. Quaternary Research, 48, 100-113.

Lyons TW (1997) Sulfur isotopic trends and pathways of iron sulfide formation in upper Holocene sediments of the anoxic Black Sea. Geochimica et Cosmochimica Acta, 61, 3367-3382.

Lyons TW, Berner RA, Anderson RF (1993) Evidence for large pre-industrial perturbations of the Black Sea chemocline. Nature, 365, 538-540.

Lyons TW, Kah LC, Gellatly AM (2004) The Precambrian sulphur isotope record of evolving atmospheric oxygen. In: The Precambrian Earth: Tempos and Events (eds Eriksson PG, Alterman W, Nelson DR, Mueller WU, Catuneanu O). Elsevier, Amsterdam, pp. 421440.

Lyons TW, Severmann S (2006) A critical look at iron paleoredox proxies: New insights from modern euxinic marine basins. Geochimica et Cosmochimica Acta, 70, 5698-5722.

Lyons TW, Werne JP, Hollander DJ, Murray RW (2003) Contrasting sulfur geochemistry and $\mathrm{Fe} / \mathrm{Al}$ and $\mathrm{Mo} / \mathrm{Al}$ ratios across the last oxic-to-anoxic transition in the Cariaco Basin, Venezuela. Chemical Geology, 195, 131-157.

Magaritz M, Taylor HP (1986) Oxygen 18/Oxygen 16 and D/H Studies of Plutonic Granitic and Metamorphic Rocks Across the Cordilleran Batholiths of Southern British Columbia. Journal of Geophysical Research, 91, 2193-2217. 
1072

1073

1074

1075

1076

1077

1078

1079

1080

1081

1082

1083

1084

1085

1086

1087

1088

1089

1090

1091

1092

1093

1094

1095

1096

1097

1098

1099

1100

1101

1102

1103

1104

1105

1106

1107

1108

1109

1110

1111

1112

1113

1114

1115

1116

1117
Mandernack KW, Krouse HR, Skei JM (2003) A stable sulfur and oxygen isotopic investigation of sulfur cycling in an anoxic marine basin, Framvaren Fjord, Norway. Chemical Geology, 195, 181-200.

Mariotti A, Germon J, Hubert P, Kaiser P, Letolle R, Tardieux A, Tardieux P (1981) Experimental determination of nitrogen kinetic isotope fractionation: Some principles; illustration for the denitrification and nitrification processes. Plant and Soil, 62, 413-430430.

Meyer K, Macalady J, Fulton J, Kump L, Schaperdoth I, Freeman K (2011) Carotenoid biomarkers as an imperfect reflection of the anoxygenic phototrophic community in meromictic Fayetteville Green Lake. Geobiology, 9, 321-329.

Michel FA, Allen DM, Grant MB (2002) Hydrogeochemistry and geothermal characteristics of the White Lake basin, South-central British Columbia, Canada. Geothermics, 31, 169194.

Mizutani Y (1972) Isotopic composition and underground temperature of the Otake geothermal water Kyushu, Japan. Geochemical Journal, 6, 67-73.

Mizutani Y, Rafter TA (1969) Oxygen Isotopic Composition of Sulphates - Part 4. New Zealand Journal of Science, 12, 60-68.

Mizutani Y, Rafter TA (1973) Isotopic behaviour of sulfate oxygen in the bacterial reduction of sulfate. Gechemical Journal, 6, 183-191.

Neretin LN, B^ttcher ME, Grinenko VA (2003) Sulfur isotope geochemistry of the Black Sea water column. Chemical Geology, 200, 59-69.

Northcote T, Hall K (2010) Salinity regulation of zooplanktonic abundance and vertical distribution in two saline meromictic lakes in south central British Columbia. Hydrobiologia, 638, 121-136.

Northcote TG, Hall KJ (1983) Limnological contrasts and anomalies in two adjacent saline lakes. Hydrobiologia, 105, 179-194.

Northcote TG, Hall KJ (1990) Vernal microstratification patterns in a meromictic saline lake: their causes and biological significance. Hydrobiologia, 197, 105-114-114.

Northcote TG, Hall KJ (2000) Short-term (decadal, annual, seasonal) changes in the limnology of a saline uni-/bimeromictic lake: causes and consequences. Verhandlugen Internationale Vereinigen für theoretische und angewandte Limnologie 27, 2652-2659.

Northcote TG, Halsey TG (1969) Seasonal changes in the limnology of some meromictic lakes in southern British Columbia. Journal Fisheries Research Board of Canada, 26, 17631787.

Ohmoto H, Lasaga AC (1982) Kinetics of reactions between aqueous sulfates and sulfides in hydrothermal systems. Geochimica et Cosmochimica Acta, 46, 1727-1745.

Overmann J (1997) Mahoney Lake: A case study of the ecological significance of phototrophic sulfur bacteria. In: Advances in Microbial Ecology (ed Jones JG). Plenum Press, New York.

Overmann J, Beatty JT, Hall KJ, Pfennig N, Northcote TG (1991) Characterization of a dense, purple sulfur bacterial layer in a meromictic salt lake. Limnology and Oceanography, 36, 846-859.

Overmann J, Beatty JT, Krouse HR, Hall KJ (1996) The sulfur cycle in the chemocline of a meromictic salt lake. Limnology and Oceanography, 4, 147-156.

Overmann J, Pfennig N (1992) Bouyancy regulation and aggregate formation in Amoebobacter purpureus from Mahoney Lake. FEMS Microbiology Letters, 101, 67-79. 
1118

1119

1120

1121

1122

1123

1124

1125

1126

1127

1128

1129

1130

1131

1132

1133

1134

1135

1136

1137

1138

1139

1140

1141

1142

1143

1144

1145

1146

1147

1148

1149

1150

1151

1152

1153

1154

1155

1156

1157

1158

1159

1160

1161

1162

Overmann J, Sandmann G, Hall KJ, Northcote TG (1993) Fossil carotenoids and paleolimnology of meromictic Mahoney Lake, British Columbia, Canada. Aquatic Sciences - Research Across Boundaries, 55, 31-39.

Overmann J, Thomas Beatty J, Hall KJ (1994) Photosynthetic activity and population dynamics of Amoebobacter purpureus in a meromictic saline lake. FEMS Microbiology Ecology, 15, 309-319.

Raiswell R, Buckley F, Berner RA, Anderson TF (1988) Degree of pyritization of iron as a paleoenvironmental indicator of bottom-water oxygenation. Journal of Sedimentary Research, 58, 812-819.

Raiswell R, Canfield DE, Berner RA (1994) A comparison of iron extraction methods for the determination of degree of pyritisation and the recognition of iron-limited pyrite formation. Chemical Geology, 111, 101-110.

Rees CE (1973) A steady-state model for sulphur isotope fractionation in bacterial reduction processes. Geochimica et Cosmochimica Acta, 37, 1141-1162.

Rees CE (1978) The sulphur isotopic composition of ocean water sulphate. Geochimica et Cosmochimica Acta, 42, 377-381.

Reinhard CT, Planavsky NJ, Robbins LJ, Partin CA, Gill BC, Lalonde SV, Bekker A, Konhauser KO, Lyons TW (2013) Proterozoic ocean redox and biogeochemical stasis. Proceedings of the National Academy of Sciences, 110, 5357-5362.

Riedinger N, Brunner B, Formolo MJ, Solomon E, Kasten S, Strasser M, Ferdelman TG (2010) Oxidative sulfur cycling in the deep biosphere of the Nankai Trough, Japan. Geology, 38, 851-854.

Rudnicki MD, Elderfield H, Spiro B (2001) Fractionation of sulfur isotopes during bacterial sulfate reduction in deep ocean sediments at elevated temperatures. Geochimica et Cosmochimica Acta, 65, 777-789.

Sheu D-D, Shakur A, Pigott JD, Wiesenburg DA, Brooks JM, Krouse HR (1988) Sulfur and oxygen isotopic compositions of dissolved sulfate in the Orca Basin: Implications for origin of the high-salinity brine and oxidation of sulfides at the brine-seawater interface. Marine Geology, 78, 303-310.

Sim MS, Bosak T, Ono S (2011) Large Sulfur Isotope Fractionation Does Not Require Disproportionation. Science, 333, 74-77.

Sørensen KB, Canfield DE (2004) Annual fluctuations in sulfur isotope fractionation in the water column of a euxinic marine basin. Geochimica et Cosmochimica Acta, 68, 503-515.

Stookey LL (1970) Ferrozine---a new spectrophotometric reagent for iron. Analytical Chemistry, 42, 779-781.

Sweeney RE, Kaplan IR (1980) Stable isotope composition of dissolved sulfate and hydrogen sulfide in the Black Sea. Marine Chemistry, 9, 145-152.

Taylor BE, Wheeler MC (1984) Isotope composition of sulphate in acid mine drainage as measure of bacterial oxidation. Nature, 308, 538-541.

Thamdrup B, Finster K, Hansen JW, Bak F (1993) Bacterial Disproportionation of Elemental Sulfur Coupled to Chemical Reduction of Iron or Manganese. Applied and Environmental Microbiology, 59, 101-108.

Turchyn AV, Brüchert V, Lyons TW, Engel GS, Balci N, Schrag DP, Brunner B (2010) Kinetic oxygen isotope effects during dissimilatory sulfate reduction: a combined theoretical and experimental approach. Geochimica et Cosmochimica Acta, 74, 2011-2024. 
1163

1164

1165

1166

1167

1168

1169

1170

1171

1172

1173

1174

1175

1176

1177

1178

1179

1180

1181

1182

1183

1184

1185

1186

1187

1188

1189

1190

1191

1192

1193

1194

1195

1196

1197

1198

1199

1200

1201

1202

1203

1204

1205

1206
Turchyn AV, Schrag DP (2006) Cenozoic evolution of the sulfur cycle: Insight from oxygen isotopes in marine sulfate. Earth and Planetary Science Letters, 241, 763-779.

Turchyn AV, Schrag DP, Coccioni R, Montanari A (2009) Stable isotope analysis of the Cretaceous sulfur cycle. Earth and Planetary Science Letters, 285, 115-123.

Van Everdingen RO, Krouse HR (1985) Isotope composition of sulphates generated by bacterial and abiological oxidation. Nature, 315, 395-396.

Ward PRB, Cousins EA, Hall KJ, Northcote TG, Murphy TP (1989) Mixing by Wind and Penetrative Convection in Small Lakes. In: International Association for Hydraulic Research, 23rd. Congress, Ottawa, Canada, pp. D-331-D-338.

Ward PRB, Hall KJ, Northcote TG, Cheung W, Murphy T (1990) Autumnal mixing in Mahoney Lake, British Columbia. Hydrobiologia, 197, 129-138-138.

Wehrmann LM, Templer SP, Brunner B, Bernasconi SM, Maignien L, Ferdelman TG (2011) The imprint of methane seepage on the geochemical record and early diagenetic processes in cold-water coral mounds on Pen Duick Escarpment, Gulf of Cadiz. Marine Geology, 282, 118-137.

West AG, Patrickson SJ, Ehleringer JR (2006) Water extraction times for plant and soil materials used in stable isotope analysis. Rapid Communications in Mass Spectrometry, 20, 13171321.

Wortmann UG, Bernasconi SM, Bottcher ME (2001) Hypersulfidic deep biosphere indicates extreme sulfur isotope fractionation during single-step microbial sulfate reduction. Geology, 29, 647-650.

Wortmann UG, Chernyavsky B, Bernasconi SM, Brunner B, B^ttcher ME, Swart PK (2007) Oxygen isotope biogeochemistry of pore water sulfate in the deep biosphere: Dominance of isotope exchange reactions with ambient water during microbial sulfate reduction (ODP Site 1130). Geochimica et Cosmochimica Acta, 71, 4221-4232.

Zak I, Saki H, Kaplan IR (1980) Factors Controlling the ${ }^{18} \mathrm{O} /{ }^{16} \mathrm{O}$ and ${ }^{34} \mathrm{~S} /{ }^{32} \mathrm{~S}$ Isotope Ratios of Ocean Sulfates, Evaporites and Interstitial Sulfates from Modern Deep Sea Sediments. In: Isotope Marine Chemistry (eds Goldberg ED, Horibe Y, Saruhashi K). Geochemistry Research Association, Tokyo, pp. 339-373.

Zeebe RE (2010) A new value for the stable oxygen isotope fractionation between dissolved sulfate ion and water. Geochimica et Cosmochimica Acta, 74, 818-828.

Zerkle AL, Farquhar J, Johnston DT, Cox RP, Canfield DE (2009) Fractionation of multiple sulfur isotopes during phototrophic oxidation of sulfide and elemental sulfur by a green sulfur bacterium. Geochimica et Cosmochimica Acta, 73, 291-306.

Zerkle AL, Kamyshny Jr A, Kump LR, Farquhar J, Oduro H, Arthur MA (2010) Sulfur cycling in a stratified euxinic lake with moderately high sulfate: Constraints from quadruple $\mathrm{S}$ isotopes. Geochimica et Cosmochimica Acta, 74, 4953-4970.

Zhang J-Z, Millero FJ (1994) Kinetics of Oxidation of Hydrogen Sulfide in Natural Waters. In: Environmental Geochemistry of Sulfide Oxidation (eds Alpers CN, Blowes DW). American Chemical Society, Washingon DC, pp. 393-409.

Zopfi J, Ferdelman TG, Jörgensen BB, Teske A, Thamdrup B (2001) Influence of water column dynamics on sulfide oxidation and other major biogeochemical processes in the chemocline of Mariager Fjord (Denmark). Marine Chemistry, 74, 29-51. 
1208

1209

1210

1211

1212

1213

1214

1215

1216

1217

1218

1219

1220

1221

1222

1223

1224

1225

1226

1227

1228

1229

1230

1231

1232

1233

1234

1235

1236

1237

1238

1239

1240

1241

1242

1243

1244

1245

1246

1247

1248

1249

1250

1251

1252

1253

Figure 1. Mahoney Lake and Green Lake are located within the White Lake Basin, British Columbia (modified after Northcote and Hall, 1983; Michel et al, 2002). Cores 2 and 3 were collected from the center of Mahoney Lake and Core 9 was taken from the oxic margin. Surface water $\delta^{34} \mathrm{~S}_{\mathrm{SO} 4}, \delta^{18} \mathrm{O}_{\mathrm{SO} 4}$, and sulfate concentrations are shown for Mahoney Lake, Green Lake, Sleeping Lake, and the upland pond (ML pond), as well as the $\delta^{34} \mathrm{~S}$ of chromium reducible sulfur extracted from a greenstone sample collected from the eastern side of the catchment. Bedrock geology transitions from meta-volcanics west of the fault-line to cherts and greenstones east of the fault. Geologic descriptions and interpretations are from Church (2002) and Northcote and Hall (1983).

Figure 2. Oxygen and hydrogen isotope data for meteoric water and surface waters in the White Lake Basin. Results from the current study include samples from the Mahoney Lake mixolimnion (ML 08 oxic) and monimolimnion (ML 08 anoxic), the upland pond (ML pond 08), and Sleeping Lake (SL 08). All remaining water data are from Michel et al., (2002). The Local Meteoric Water Line (LMWL) is shown for Penticton precipitation data (squares) in comparison to the Global Meteoric Water Line (GMWL; $\delta \mathrm{D}=8 \delta^{18} \mathrm{O}+10$ ). Data for deep wells (open diamonds; 76 to $549 \mathrm{~m}$ deep), shallow wells drilled in overburden (filled diamonds), springs (triangles), and surface waters (circles) all plot along a local evaporation line (LEL) with a slope of $4.7\left(\mathrm{R}^{2}=0.99\right)$. The inset shows LEL relative to the isotopic composition of Vienna Standard Mean Oceanwater (VSMOW) and Okanagan granitic batholiths (Magaritz and Taylor, 1986).

Figure 3. Water column profiles of temperature, specific conductivity $(\mathrm{SpC}), \mathrm{pH}$, dissolved oxygen (DO), dissolved sulfide $\left(\mathrm{H}_{2} \mathrm{~S}\right)$, light intensity, and turbidity for (A) Mahoney and Green Lake in September 2006, and (B) Mahoney Lake in July 2008. Extinction coefficients $(k)$ were calculated for light attenuation above $(k=0.400)$ and below the chemocline $(k=3.347)$ in Mahoney Lake, July 2008.

Figure 4. Mahoney Lake water column profiles of chloride and sulfate concentrations, $\mathrm{SO}_{4} / \mathrm{Cl}$ (molar), $\delta^{34} \mathrm{~S}_{\mathrm{H} 2 \mathrm{~S}}, \delta^{34} \mathrm{~S}_{\mathrm{SO} 4}$, and $\delta^{18} \mathrm{O}_{\mathrm{SO} 4}$ for samples collected in September 2006 (filled symbols) and July 2008 (open symbols). Vertical shaded regions are the mean plus standard deviations for concentrations $\left([\mathrm{Cl}]=57.7 \pm 1.7 \mathrm{mM} ;\left[\mathrm{SO}_{4}\right]=341 \pm 20.1 \mathrm{mM}\right)$ or molar ratios $\left(\mathrm{SO}_{4} / \mathrm{Cl}=5.9 \pm\right.$ 0.2 ) within the upper $5 \mathrm{~m}$ of the (oxygenated) water column.

Figure 5. Mahoney Lake (A) solid phase sulfur concentrations, DOS, and (B) solid phase and pore water isotope data for sediments collected below the chemocline (Core 2 and 3 ) and below oxygenated bottom water (Core 9). Vertical shaded regions (B) indicate the average stable isotope value ( \pm standard deviation) of water column sulfate and sulfide.

Figure 6. Mahoney Lake sulfur isotope fractionation $\left(\Delta^{34} \mathrm{~S}_{\mathrm{SO} 4-\mathrm{H} 2 \mathrm{~S}}=\delta^{34} \mathrm{~S}_{\mathrm{SO} 4}-\delta^{34} \mathrm{~S}_{\mathrm{H} 2 \mathrm{~S}}\right)$ within the water column (round symbols) and averaged pore water values from Cores 2 and 3 (open diamonds) and Core 9 (filled diamonds) plotted against depth. Error bars represent standard 
1254 deviation for fractionations. Cores 2 and 3 were collected below the chemocline and Core 9 was 1255 collected below oxygenated bottom waters.

1256

1257

1258

1259

1260

1261

1262

1263

1264

1265

1266

1267

1268

1269

1270

1271

1272

1273

Figure 7. Sulfate sulfur and oxygen isotope cross-plots of Mahoney Lake water column sulfate collected in September 2006 (filled symbols) and July 2008 (open symbols). The data are bounded by model arrays (A) that define the expected trajectories of rapid sulfate reduction, Trend $\mathrm{A}$, and slow rates of sulfate reduction, Trend $\mathrm{B}$, based on the initial isotopic compositions for Mahoney Lake sulfate $\left(\delta^{34} \mathrm{~S}_{\mathrm{SO} 4}=21.5 \%\right.$ and $\delta^{18} \mathrm{O}_{\mathrm{SO} 4}=16.5 \%$; filled square $)$ and water $\left(\delta^{18} \mathrm{O}_{\text {water }}=-0.3 \%\right.$ ) . The data collected in the fall (B) have a higher slope than the those collected in the summer $(\mathrm{C})$.

Figure 8. Mixing plots ( $\delta$ vs. 1/concentration) of sulfate (A) sulfur isotope and (B) oxygen isotope values relative to sulfate concentration for Mahoney Lake water column (round symbols) and power waters (diamonds) collected from anoxic (open symbols) or oxic (closed symbols) bottom waters. 


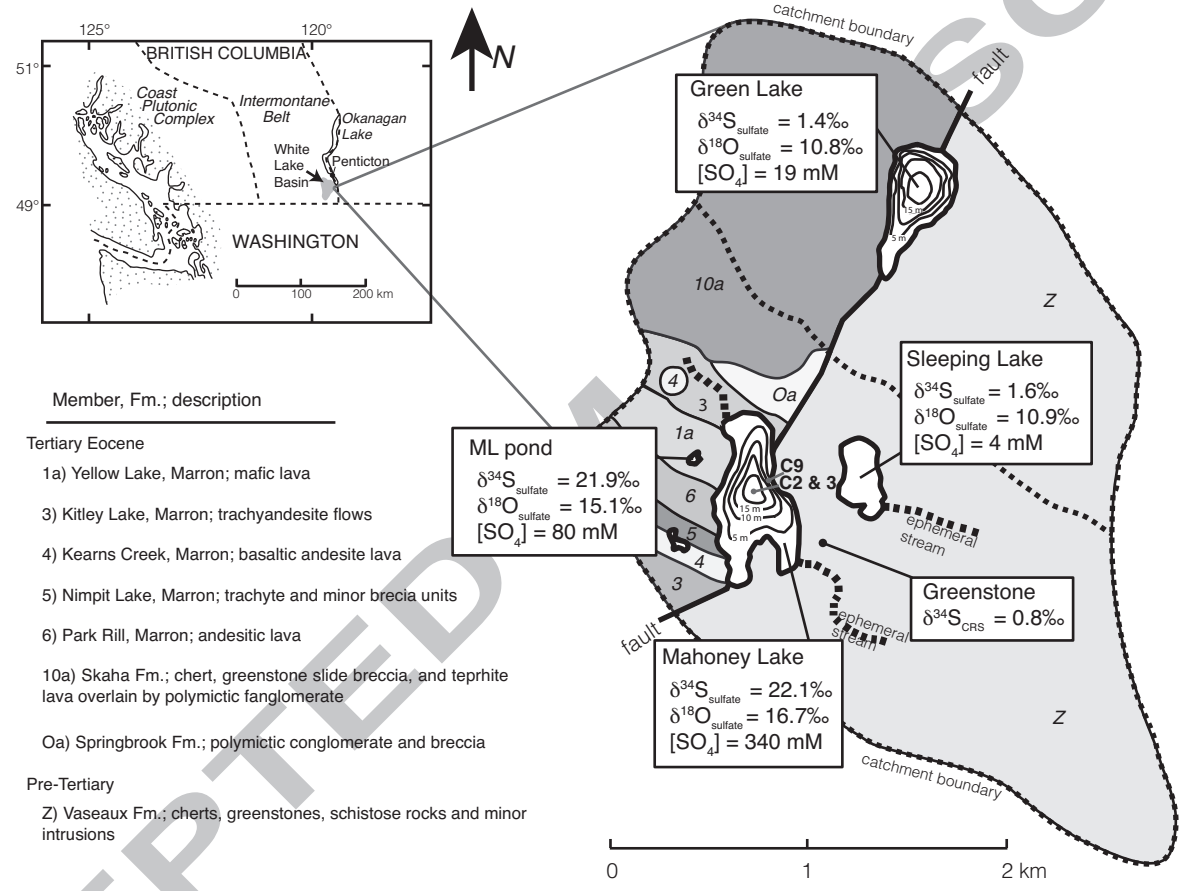




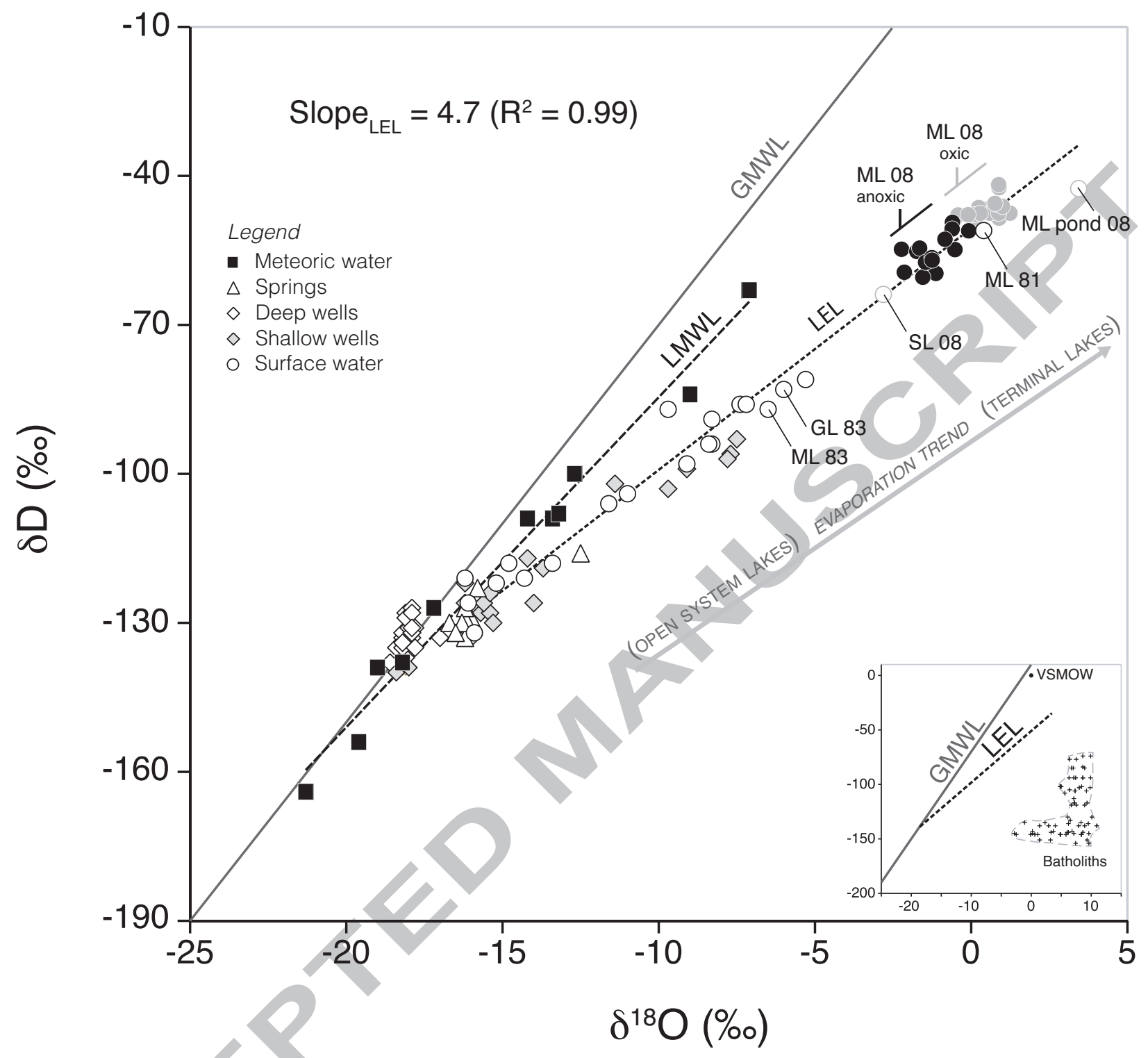

1276 

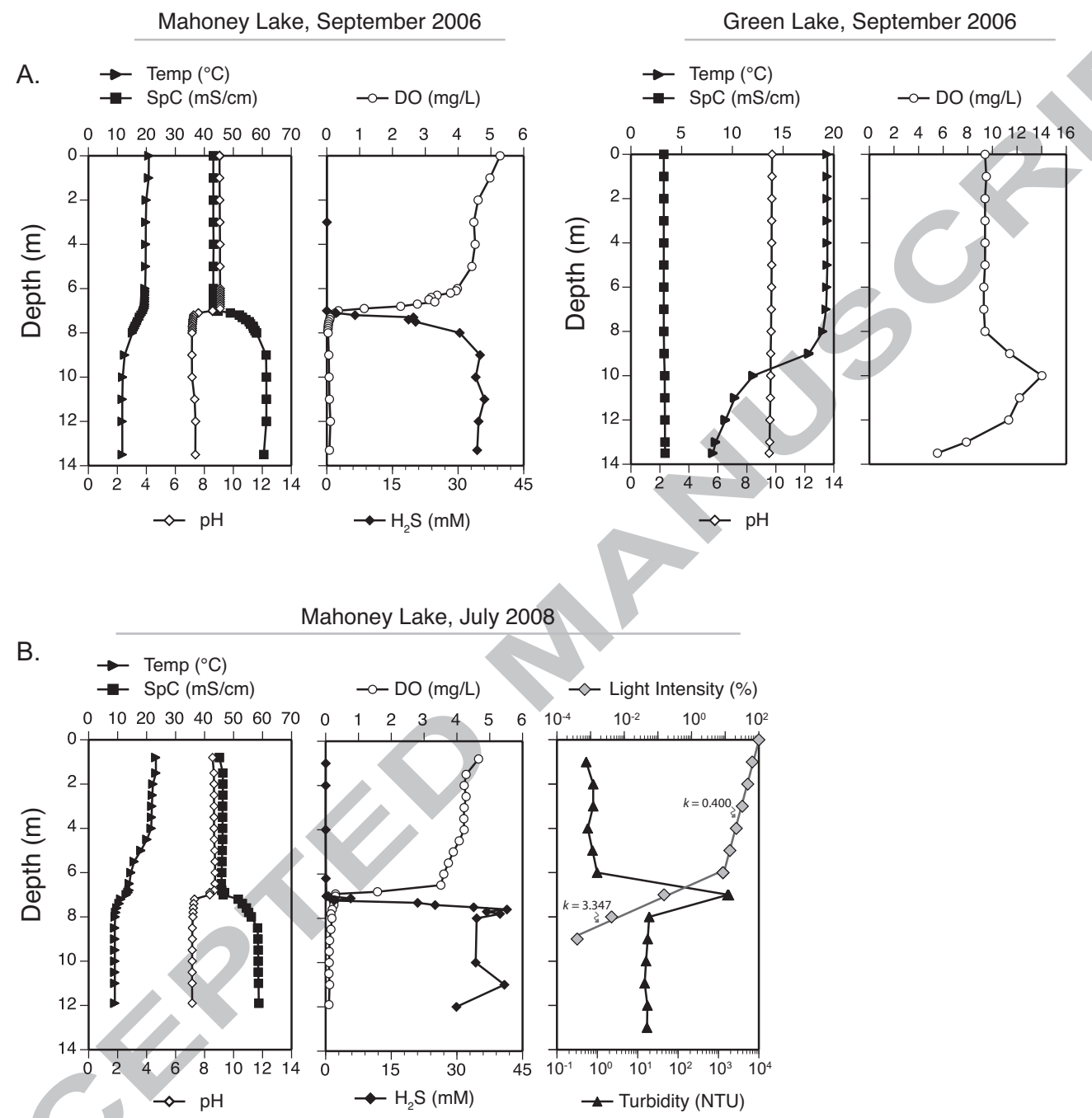


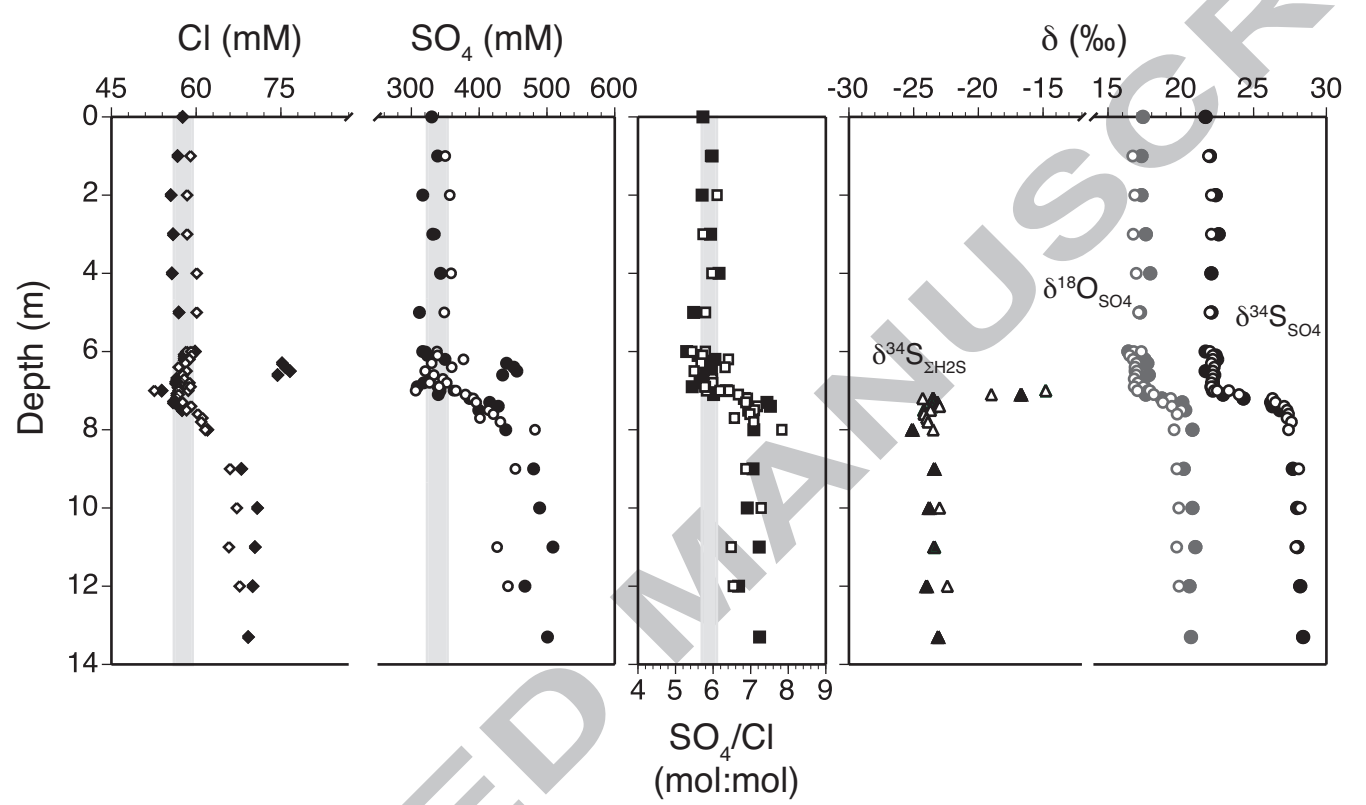


Anoxic bottom waters

A. Core 2

$\mathrm{S}$ (wt\%), DOS

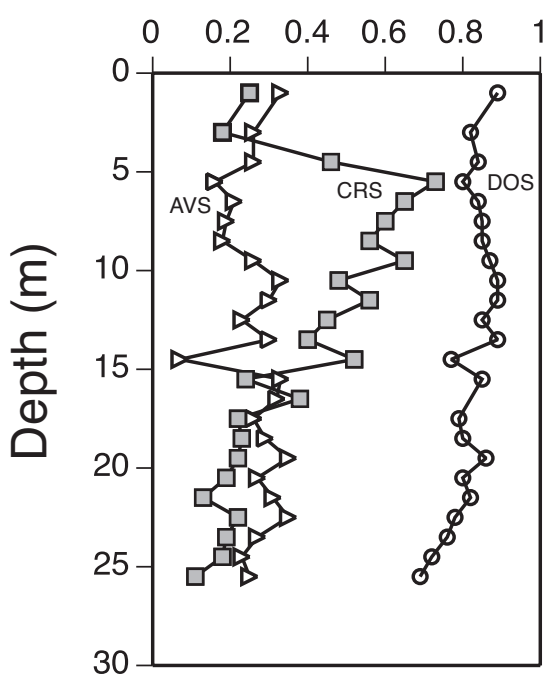

Core 3

$S(w t \%)$, DOS
Oxic bottom waters

Core 9

$\mathrm{S}(\mathrm{wt} \%), \mathrm{DOS}$

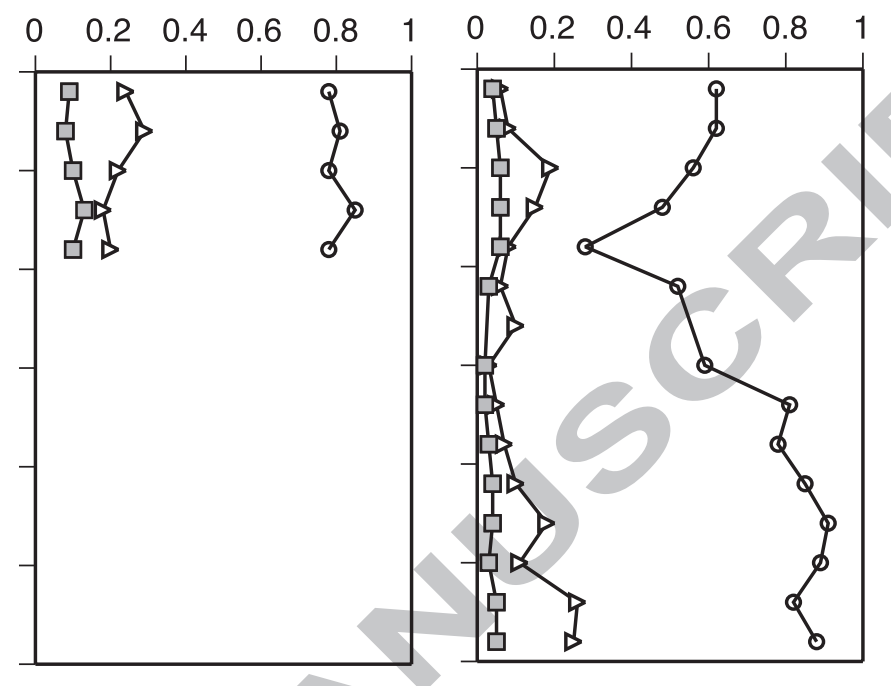

B.

Core 2

Core 3

Core 9

$\delta(\%)$

$\delta(\%)$

$\delta(\%)$

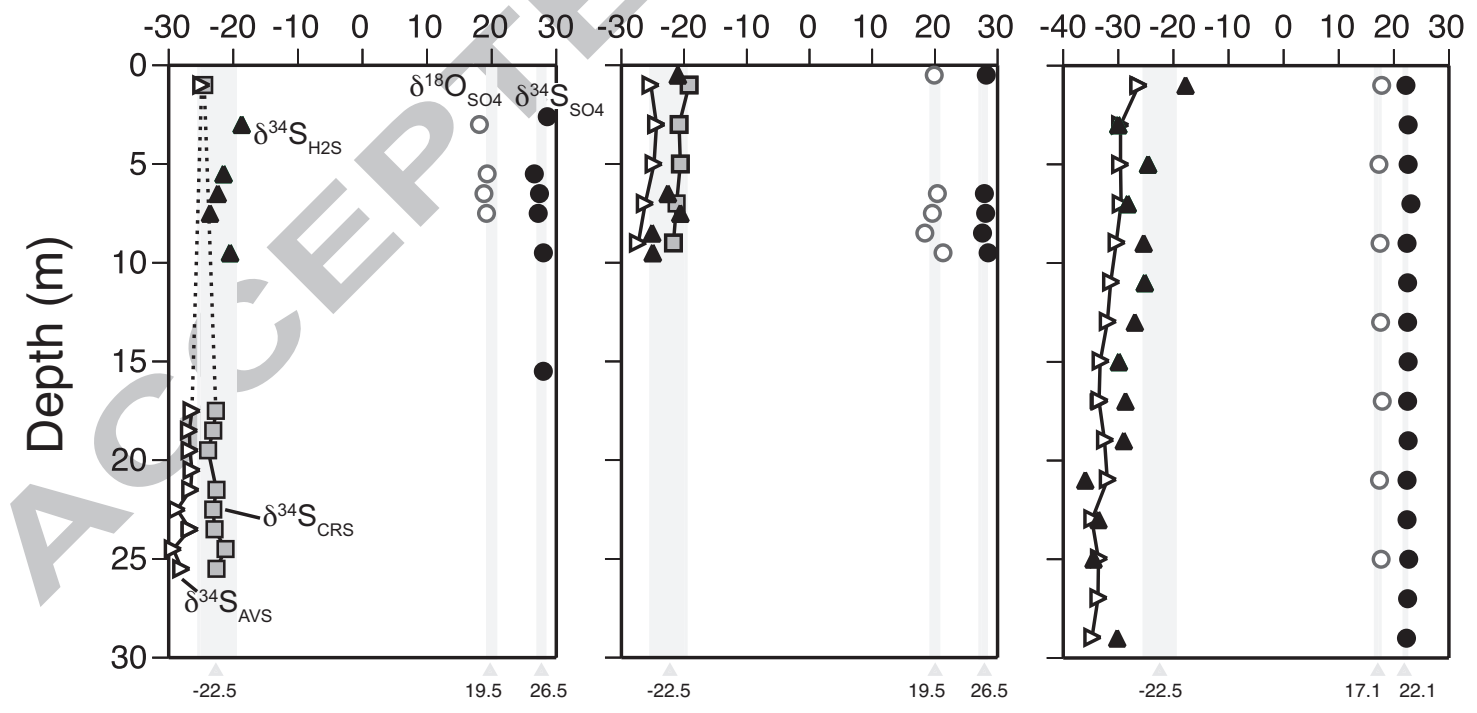




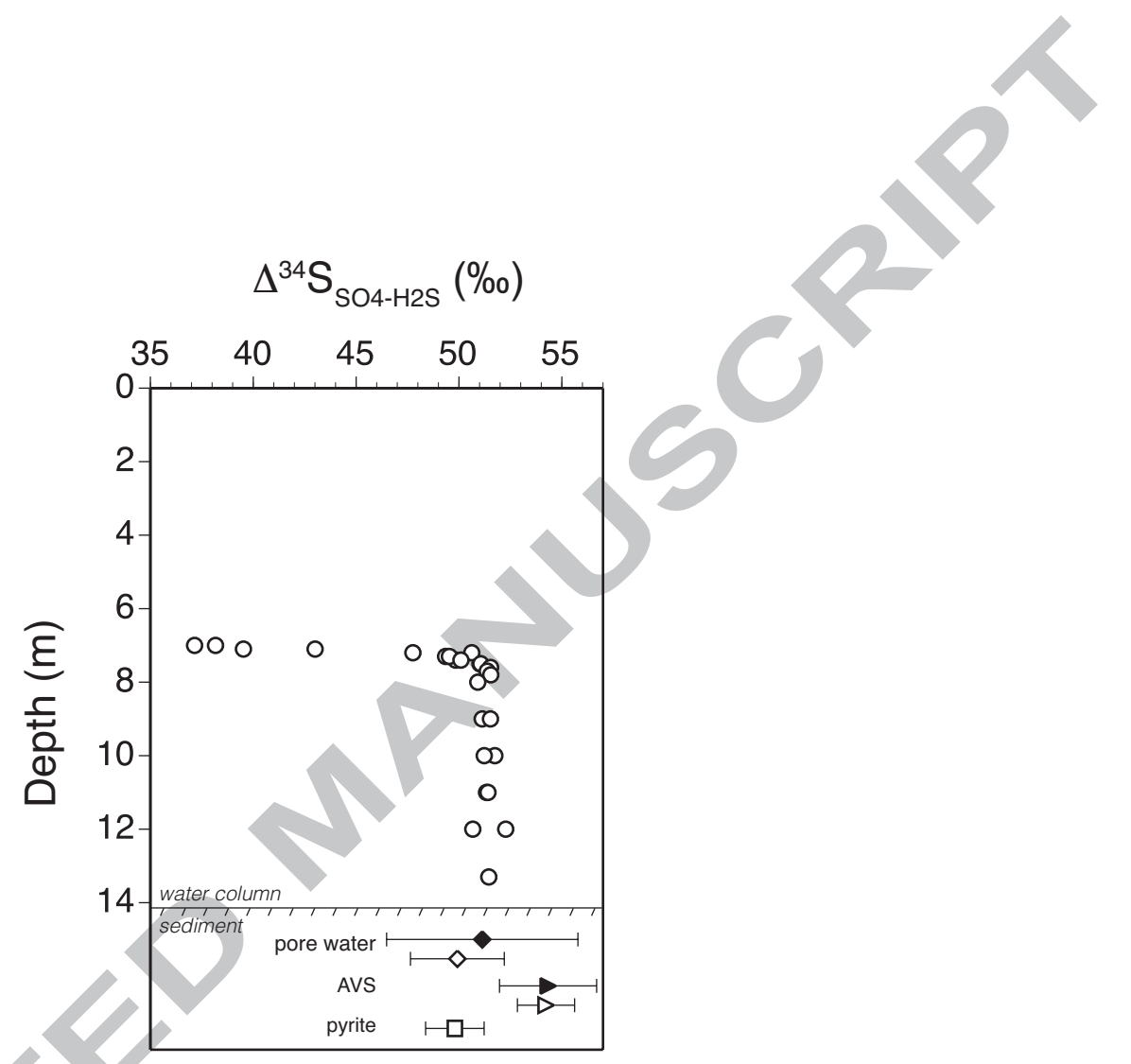


A.

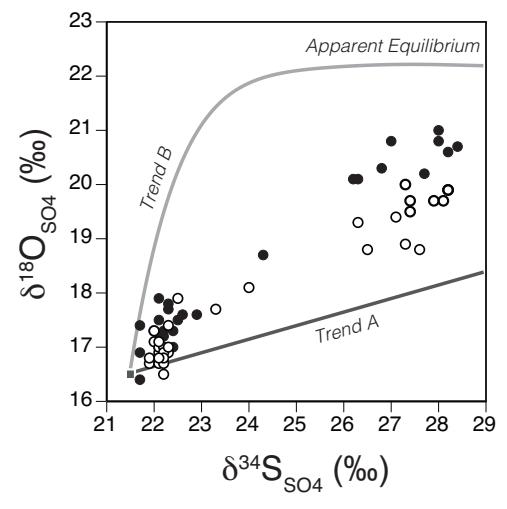

B.

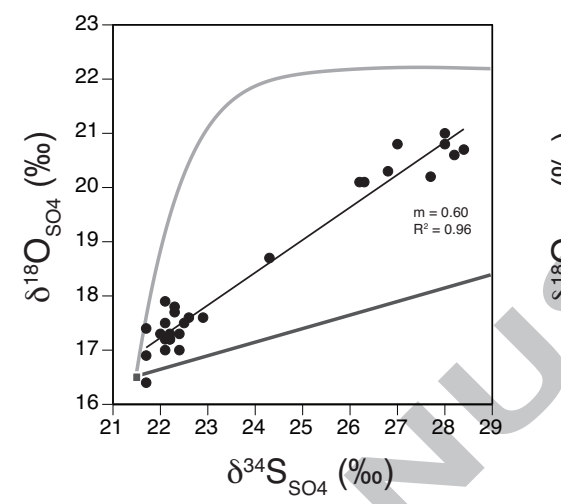

C.

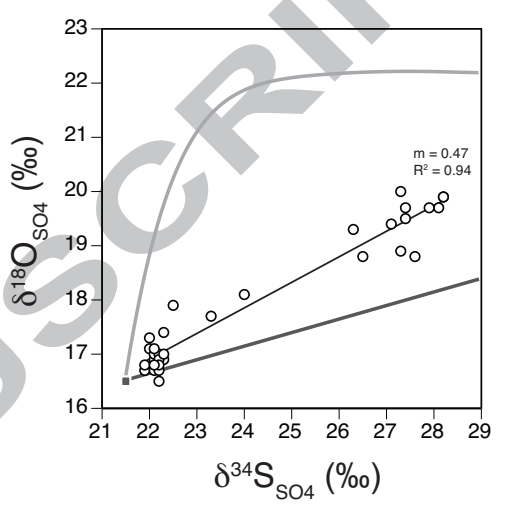


A.

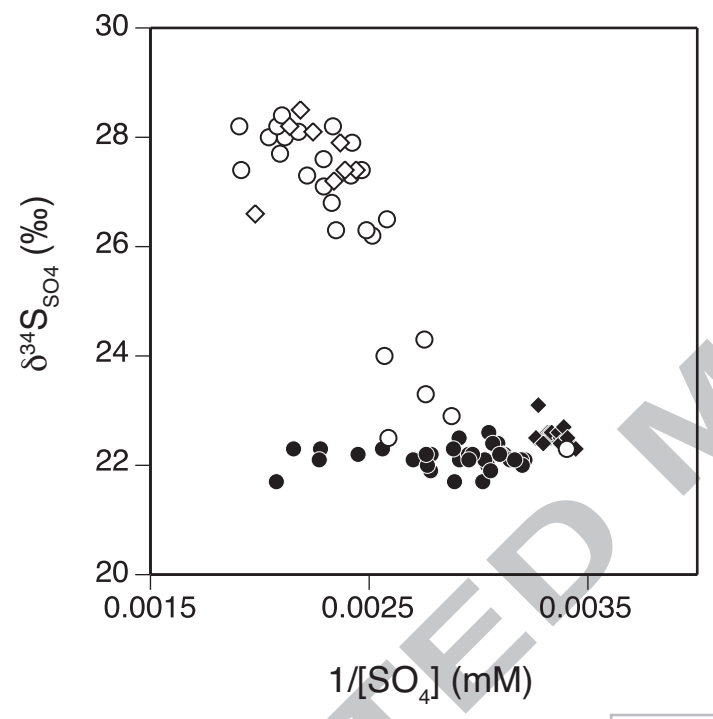

B.

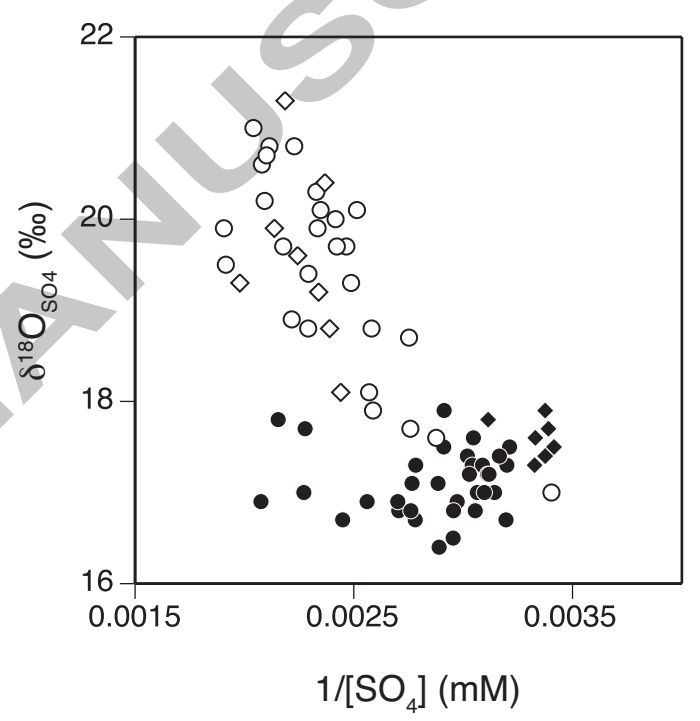

Legend: WC ० anoxic BW (open)

PW $\diamond$ oxic BW (filled) 
1289 Table 1. Water column concentration and isotope data.

\begin{tabular}{|c|c|c|c|c|c|c|c|c|c|c|c|}
\hline \multirow{3}{*}{ Lake } & Dep & $\Sigma \mathrm{H}_{2}$ & & & $\delta^{18} \mathrm{O}$ & $\delta^{34} S$ & $\delta^{34} S$ & $\Delta^{34} \mathrm{~S}_{\mathrm{SO} 4}$ & $\delta^{34} S_{\text {Elem }}$ & $\delta^{18} \mathrm{O}$ & $\delta^{2} \mathrm{H}_{\mathrm{H}}$ \\
\hline & th & $\begin{array}{c}\mathrm{S} \\
(\mathrm{m}\end{array}$ & $\begin{array}{c}\mathrm{SO}_{4} \\
(\mathrm{~m}\end{array}$ & $\begin{array}{l}\mathrm{Cl} \\
(\mathrm{m}\end{array}$ & SO4 & SO4 & $\mathrm{H} 2 \mathrm{~S}$ & $-\mathrm{H} 2 \mathrm{~S}$ & S & $\mathrm{H} 2 \mathrm{O}$ & $2 \mathrm{O}$ \\
\hline & (m) & M) & M) & M) & $(\% o)$ & $(\% o)$ & $(\% o)$ & $(\% o)$ & $(\% \circ)$ & $(\% o)$ & $(\% 0)$ \\
\hline
\end{tabular}

\section{September} 2006

Green

24.

Lake

$0 \quad-\quad 94$

$1.4 \quad 11.6 \quad 5.2$

19.

$\begin{array}{llllll}1 & - & 90 & 0.4 & 10.5 & 1.2\end{array}$

20.

$\begin{array}{llllll}2 & - & 74 & 0.2 & 10.2 & 1.2\end{array}$

18.

$\begin{array}{llllll}3 & - & 52 & 0.4 & 10.9 & 1.2\end{array}$

$\begin{array}{llllll} & & 20 . & & & \\ 4 & - & 04 & 0.4 & 10.6 & 1.0\end{array}$

19. 0.0

$\begin{array}{llllll}5 & - & 33 & 1 & 10.7 & 0.5\end{array}$

20.

$\begin{array}{llllll}6 & - & 22 & - & 10.5 & 1.1\end{array}$

20.

$7 \quad-\quad 29$

$\begin{array}{lll}2.3 & 10.5 & 1.1\end{array}$

20.

$\begin{array}{llllll}9 & - & 09 & 1.3 & 11.2 & 1.1\end{array}$

20.

$\begin{array}{llllll}10 & - & 90 & 0.7 & 11.0 & 1.2\end{array}$ 21.
11
$\begin{array}{llll}30 & 0.7 & - & 1.0\end{array}$

21.

$12 \quad-\quad 71$

20.

$\begin{array}{llllll}13 & - & 13 & - & 11.1 & 0.7\end{array}$

Mahoney 33157.

Lake .26 32856.

$\begin{array}{llllll}1 & - & .8 & 7 & 17.3 & 22.0\end{array}$ 32355 .

$\begin{array}{llllll}2 & - & .8 & 5 & 17.3 & 22.4\end{array}$ $\begin{array}{lll}0.0 & 328 & 55 .\end{array}$

$\begin{array}{llllll}3 & 29 & .2 & 9 & 17.6 & 22.6\end{array}$ 34355.

$\begin{array}{llllll}4 & - & .3 & 7 & 17.9 & 22.1\end{array}$ 33056.

$\begin{array}{llllll}5 & - & .2 & 9 & 17.2 & 22.1\end{array}$ 


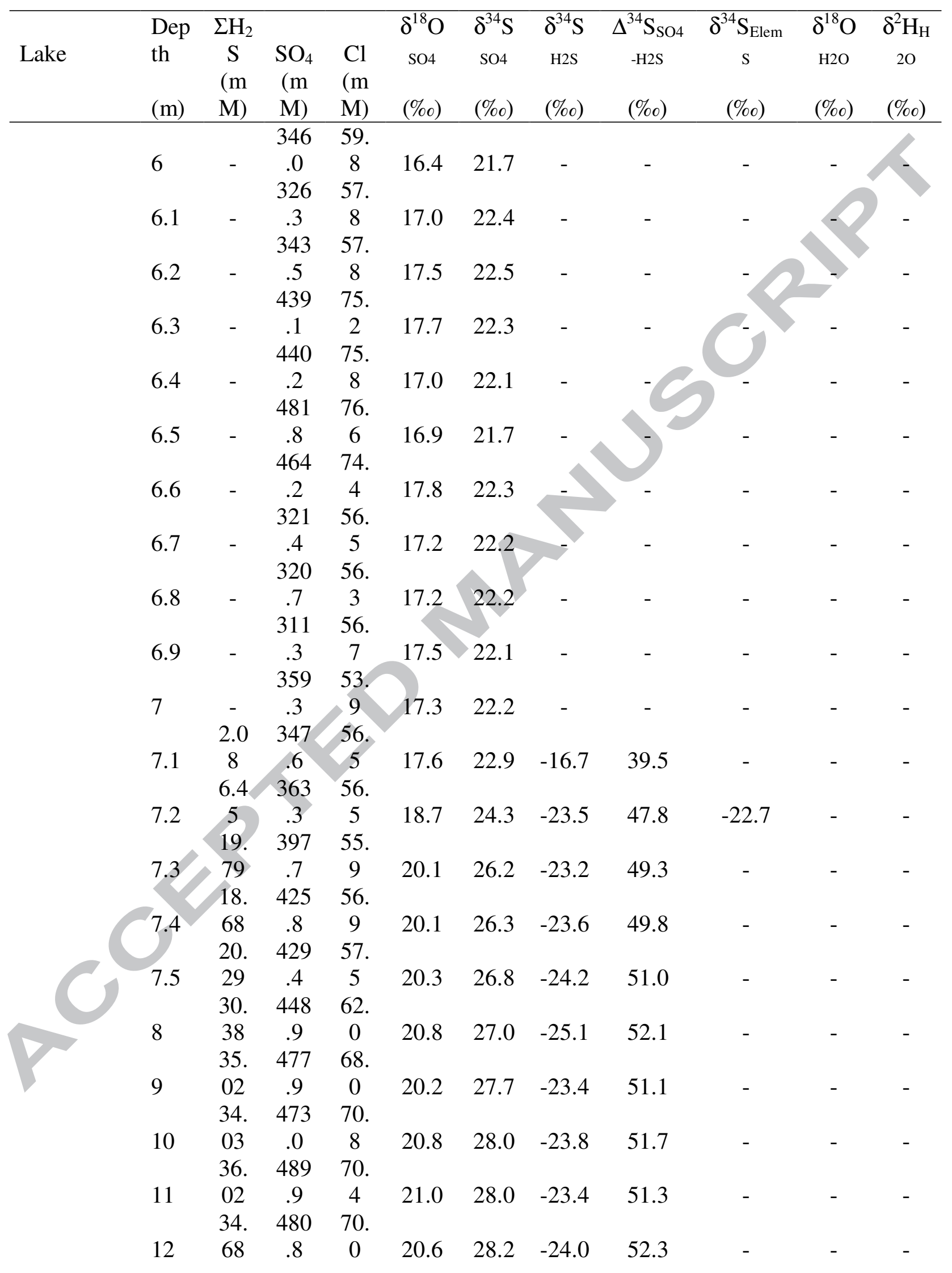




\begin{tabular}{|c|c|c|c|c|c|c|c|c|c|c|c|}
\hline \multirow{3}{*}{ Lake } & Dep & $\Sigma \mathrm{H}_{2}$ & & & $\delta^{18} \mathrm{O}$ & $\delta^{34} S$ & $\delta^{34} S$ & $\Delta^{34} \mathrm{~S}_{\mathrm{SO} 4}$ & $\delta^{34} S_{\text {Elem }}$ & $\delta^{18} \mathrm{O}$ & $\delta^{2} \mathrm{H}_{\mathrm{H}}$ \\
\hline & th & $\begin{array}{c}\mathrm{S} \\
(\mathrm{m}\end{array}$ & $\begin{array}{c}\mathrm{SO}_{4} \\
(\mathrm{~m}\end{array}$ & $\begin{array}{l}\mathrm{Cl} \\
(\mathrm{m}\end{array}$ & $\mathrm{SO} 4$ & $\mathrm{SO} 4$ & $\mathrm{H} 2 \mathrm{~S}$ & $-\mathrm{H} 2 \mathrm{~S}$ & $S$ & $\mathrm{H} 2 \mathrm{O}$ & 20 \\
\hline & $(\mathrm{m})$ & M) & M) & M) & $(\% o)$ & $(\% o)$ & $(\% o)$ & $(\% \circ)$ & $(\% \circ)$ & $(\% o)$ & $(\% o)$ \\
\hline & & 34. & 475 & 69. & & & & & & & \\
\hline & 13.3 & 36 & .9 & 2 & 20.7 & 28.4 & -23.1 & 51.4 & - & - & \\
\hline
\end{tabular}

July 2008

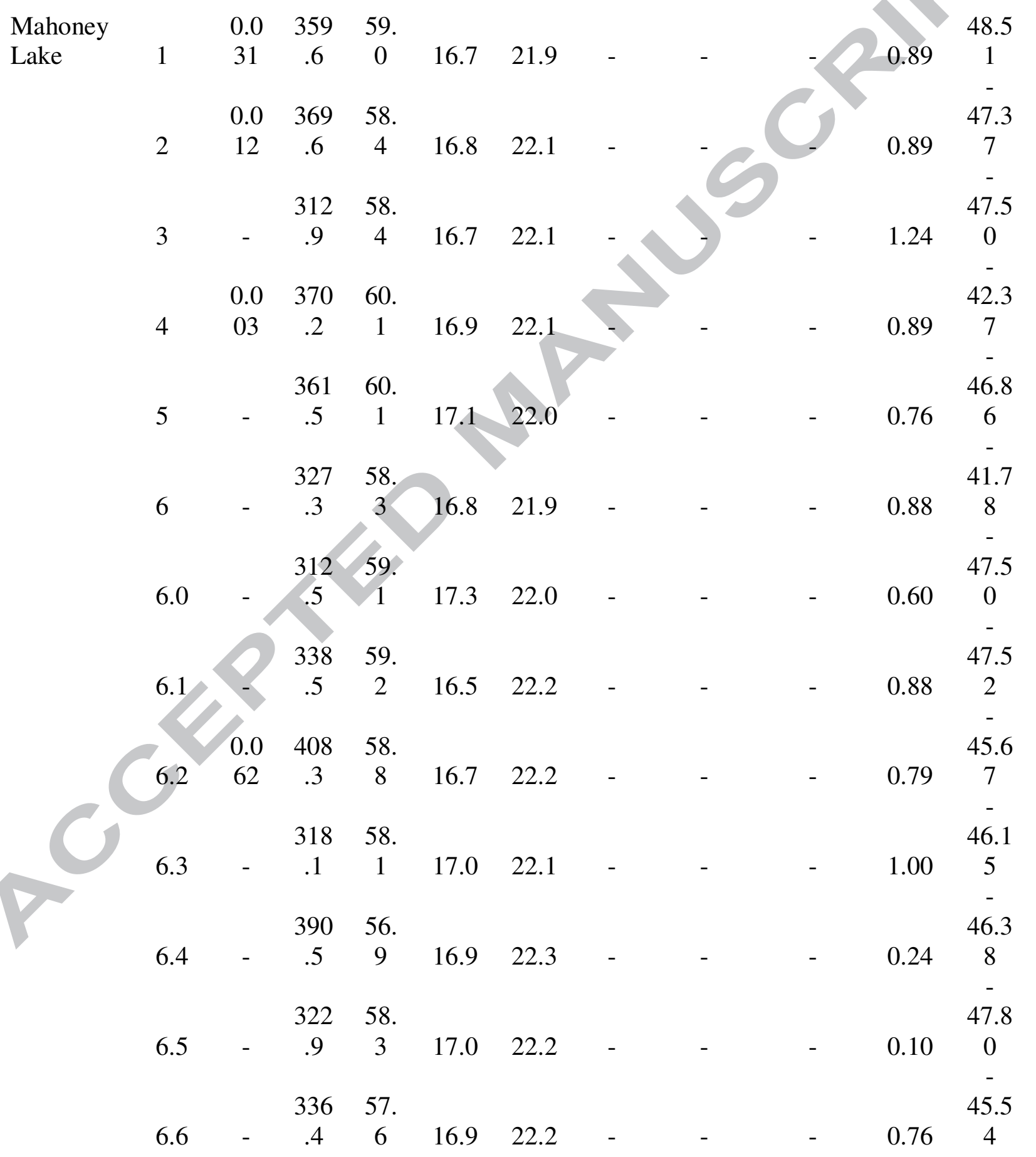




\begin{tabular}{|c|c|c|c|c|c|c|c|c|c|c|c|}
\hline Lake & $\begin{array}{l}\begin{array}{l}\text { Dep } \\
\text { th }\end{array} \\
(\mathrm{m}) \\
\end{array}$ & $\begin{array}{c}\mathrm{H}_{2} \\
\mathrm{~S} \\
(\mathrm{~m} \\
\mathrm{M}) \\
\end{array}$ & $\begin{array}{c}\mathrm{SO}_{4} \\
(\mathrm{~m} \\
\mathrm{M}) \\
\end{array}$ & $\begin{array}{l}\mathrm{Cl} \\
(\mathrm{m} \\
\mathrm{M})\end{array}$ & $\begin{array}{c}\delta^{18} \mathrm{O} \\
\mathrm{sO} 4 \\
(\%) \\
\end{array}$ & $\begin{array}{c}\delta^{34} \mathrm{~S} \\
\mathrm{SO} 4 \\
(\% 0) \\
\end{array}$ & $\begin{array}{c}\delta^{34} S \\
\mathrm{H} 2 \mathrm{~S} \\
(\% 0) \\
\end{array}$ & $\begin{array}{c}\Delta^{34} \mathrm{~S}_{\mathrm{SO} 4} \\
-\mathrm{H} 2 \mathrm{~S} \\
(\% \mathrm{o}) \\
\end{array}$ & $\begin{array}{c}\delta^{34} \mathrm{~S}_{\text {Elem }} \\
\mathrm{s} \\
(\% \circ) \\
\end{array}$ & $\begin{array}{c}\delta^{18} \mathrm{O} \\
\mathrm{H} 2 \mathrm{O} \\
(\%) \\
\end{array}$ & $\begin{array}{c}\delta^{2} \mathrm{H}_{\mathrm{H}} \\
\\
(\% \circ) \\
\end{array}$ \\
\hline & & & 362 & 57. & & & & & & & 47.8 \\
\hline & 6.7 & - & $\begin{array}{c}.2 \\
352\end{array}$ & $\begin{array}{c}9 \\
58 .\end{array}$ & 16.8 & 22.2 & - & - & - & -0.42 & $\begin{array}{c}7 \\
- \\
47.5\end{array}$ \\
\hline & 6.8 & - & .2 & 8 & - & - & - & - & - & 0.29 & 2 \\
\hline & & & 315 & 57. & & & & & & & 46.6 \\
\hline & 6.8 & - & $\begin{array}{c}.9 \\
346\end{array}$ & $\begin{array}{c}4 \\
58\end{array}$ & 17.1 & 22.1 & - & - & & 0.53 & 8 \\
\hline & 6.9 & - & .6 & 4 & 17.4 & 22.3 & - & & - & - & - \\
\hline & & & 338 & 59. & & & & & & & 48.8 \\
\hline & 6.9 & - & .3 & 0 & 16.8 & 22.1 & & - & - & 0.11 & 9 \\
\hline & & 0.1 & 386 & 56. & & & & & & & \\
\hline & 7.0 & 9 & .4 & 9 & 17.9 & 22.5 & & - & - & - & - \\
\hline & & 0.2 & 293 & 52. & & & & & $-20.0,-$ & & 54.8 \\
\hline & 7.0 & 4 & .8 & 6 & 17.0 & 22.3 & -14.8 & 37.1 & 20.8 & -0.52 & $\begin{array}{l}4 \\
-\end{array}$ \\
\hline & & 0.6 & 362 & 58. & & & & & & & 47.8 \\
\hline & 7.0 & 5 & .5 & 6 & 17.7 & 23.3 & -14.8 & 38.2 & - & -0.10 & 2 \\
\hline & & 5.7 & 389 & 56. & & & & & & & 49.3 \\
\hline & 7.1 & 2 & 1 & 9 & 18.1 & 24.0 & -19.0 & 43.0 & - & -0.60 & 6 \\
\hline & & 2 & 402 & 56. & & & & & & & 50.6 \\
\hline & 7 & 3 & .0 & 6 & 19.3 & 26.3 & -24.3 & 50.6 & - & -0.61 & $\begin{array}{l}9 \\
-\end{array}$ \\
\hline & & 21. & 387 & 57. & & & & & & & 52.7 \\
\hline & 7.3 & 02 & .4 & 6 & 18.8 & 26.5 & -23.1 & 49.5 & - & -0.84 & 6 \\
\hline & & 25. & 436 & 59. & & & & & & & 51.0 \\
\hline & 7.4 & 02 & .2 & 1 & 19.4 & 27.1 & -23.0 & 50.1 & - & -0.08 & 6 \\
\hline & & 33. & 413 & 58. & & & & & & & 54.5 \\
\hline & 7.5 & 83 & .8 & 3 & 20.0 & 27.3 & -23.7 & 51.1 & - & -1.65 & 5 \\
\hline & & 41. & 405 & 60 & & & & & & & 57.4 \\
\hline & 7.6 & 44 & .5 & 3 & 19.7 & 27.4 & -24.2 & 51.5 & - & -1.46 & 0 \\
\hline & & 36. & 451 & 61. & & & & & & & - \\
\hline & 7.7 & 83 & .2 & 1 & 18.9 & 27.3 & -24.0 & 51.4 & - & -1.26 & 56.4 \\
\hline
\end{tabular}




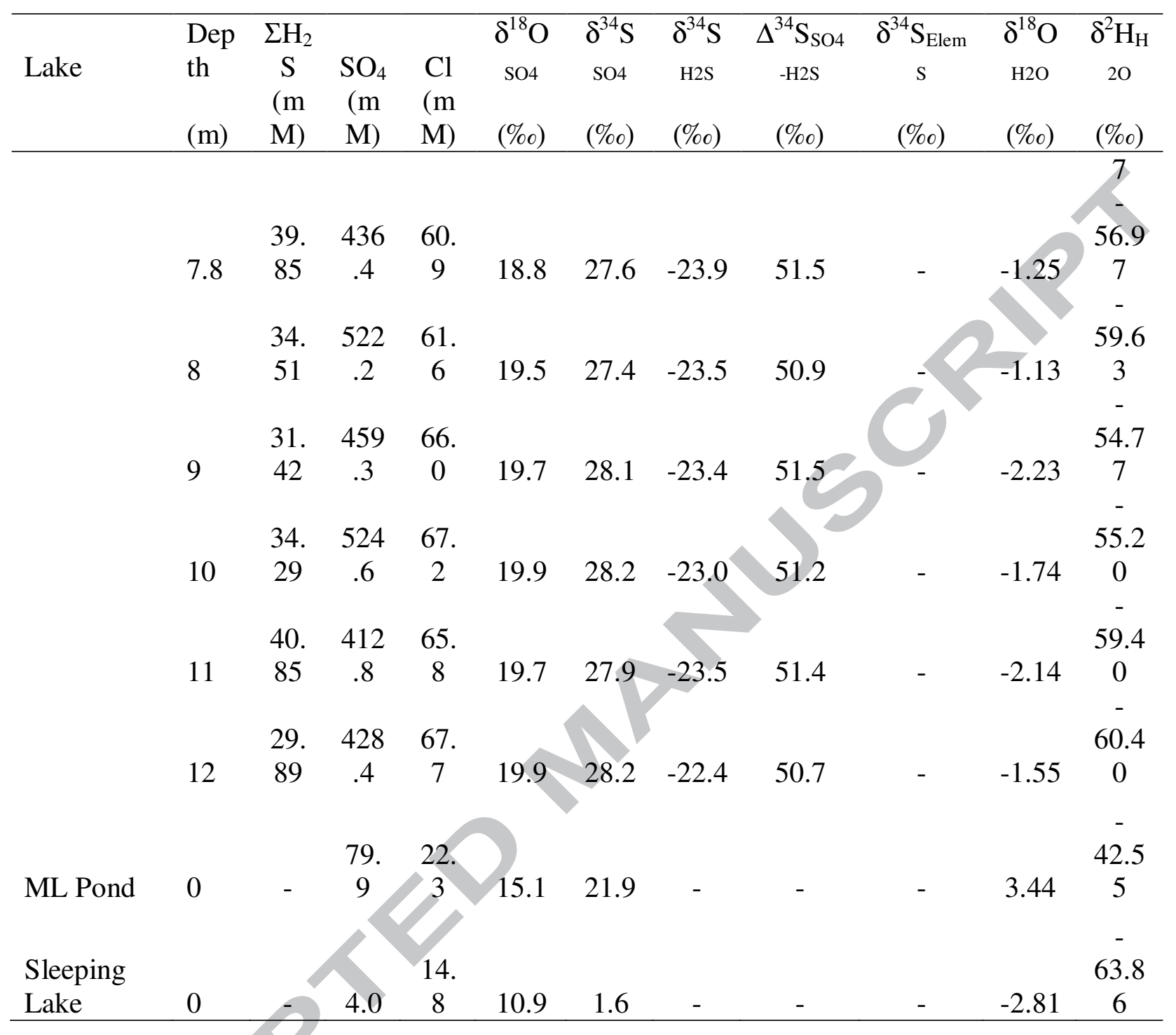


Table 2. Concentration and isotope data for solid phase sulfur species extracted from Mahoney Lake sediment cores recovered below the chemocline (Anoxic cores) and above the interface (Oxic core).

\begin{tabular}{|c|c|c|c|c|c|c|c|c|c|c|}
\hline Core & $\begin{array}{l}\text { Depth } \\
(\mathrm{cm})\end{array}$ & $\begin{array}{l}\text { AVS-S } \\
\text { (wt. \%) }\end{array}$ & $\begin{array}{c}\text { Pyrite-S } \\
\text { (wt. \%) }\end{array}$ & $\begin{array}{l}\mathrm{Fe}_{\mathrm{HCl}} \\
(\mathrm{ppm})\end{array}$ & DOS & $\begin{array}{c}\delta^{34} \mathrm{~S}_{\mathrm{AVS}} \\
(\% \circ)\end{array}$ & $\begin{array}{c}\delta^{34} S_{\text {Pyrite }} \\
(\% 0)\end{array}$ & $\begin{array}{c}\delta^{34} \mathrm{~S}_{\text {organic }} \\
(\% \circ)\end{array}$ & $\begin{array}{c}\Delta^{34} \mathrm{~S}_{\mathrm{SO} 4-\mathrm{AVS}}{ }^{*} \\
(\% \circ)\end{array}$ & $\begin{array}{c}\Delta^{34} \mathrm{~S}_{\mathrm{SO} 4-\mathrm{Pyrite}} \\
(\% \mathrm{*})\end{array}$ \\
\hline \multicolumn{11}{|c|}{ Anoxic cores } \\
\hline \multirow[t]{24}{*}{ Core 2} & 1 & 0.33 & 0.25 & 967.1 & 0.89 & -24.9 & -24.5 & - & 52.6 & 52.2 \\
\hline & 3 & 0.26 & 0.18 & 1357.4 & 0.82 & - & - & -19.3 & & - \\
\hline & 4.5 & 0.26 & 0.46 & 1571.9 & 0.84 & - & - & -20.9 & & - \\
\hline & 5.5 & 0.16 & 0.73 & 2376.4 & 0.80 & - & - & - & & - \\
\hline & 6.5 & 0.21 & 0.65 & 1750.9 & 0.84 & - & - & - & - & - \\
\hline & 7.5 & 0.19 & 0.60 & 1510.1 & 0.85 & - & - & - & - & - \\
\hline & 8.5 & 0.18 & 0.56 & 1409.4 & 0.85 & - & - & - & - & - \\
\hline & 9.5 & 0.26 & 0.65 & 1548.7 & 0.87 & - & - & & - & - \\
\hline & 10.5 & 0.33 & 0.48 & 1196.3 & 0.89 & - & - & - & - & - \\
\hline & 11.5 & 0.30 & 0.56 & 1282.0 & 0.89 & - & - & - & - & - \\
\hline & 12.5 & 0.23 & 0.45 & 1417.5 & 0.85 & - & & - & - & - \\
\hline & 13.5 & 0.30 & 0.40 & 1068.2 & 0.89 & - & & - & - & - \\
\hline & 14.5 & 0.07 & 0.52 & 1716.5 & 0.77 & - & - & - & - & - \\
\hline & 15.5 & 0.33 & 0.24 & 1437.5 & 0.85 & - & - & - & - & - \\
\hline & 16.5 & 0.32 & 0.38 & - & - & - & - & - & - & - \\
\hline & 17.5 & 0.26 & 0.22 & 1700.1 & 0.79 & -26.4 & -22.7 & - & 54.1 & 50.3 \\
\hline & 18.5 & 0.29 & 0.23 & 1782.9 & 0.80 & -26.8 & -23.1 & - & 54.5 & 50.7 \\
\hline & 19.5 & 0.35 & 0.22 & 1303.7 & 0.86 & -26.7 & -23.9 & - & 54.4 & 51.5 \\
\hline & 20.5 & 0.27 & 0.19 & 1660.0 & 0.80 & -26.4 & - & - & 54.1 & - \\
\hline & 21.5 & 0.31 & 0.13 & 1489.0 & 0.82 & -26.6 & -22.6 & - & 54.2 & 50.2 \\
\hline & 22.5 & 0.35 & 0.22 & 2230.8 & 0.78 & -28.7 & -23.1 & - & 56.4 & 50.8 \\
\hline & 23.5 & 0.27 & 0.19 & 2076.9 & 0.76 & -26.7 & -22.9 & - & 54.3 & 50.6 \\
\hline & 24.5 & 0.23 & 0.18 & 2227.8 & 0.72 & -29.3 & -21.2 & - & 56.9 & 48.9 \\
\hline & 25.5 & 0.25 & 0.11 & 2472.4 & 0.69 & -28.0 & -22.6 & - & 55.7 & 50.2 \\
\hline \multirow[t]{3}{*}{ Core 3} & 1 & 0.24 & 0.09 & 1462.4 & 0.78 & -25.3 & -19.2 & -18.7 & 53.0 & 46.9 \\
\hline & 3 & 0.29 & 0.08 & 1338.7 & 0.81 & -24.4 & -20.8 & -19.3 & 52.1 & 48.4 \\
\hline & 5 & 0.22 & 0.10 & 1350.4 & 0.78 & -24.8 & -20.6 & - & 52.4 & 48.3 \\
\hline
\end{tabular}




\begin{tabular}{|c|c|c|c|c|c|c|c|c|c|c|}
\hline Core & $\begin{array}{l}\text { Depth } \\
(\mathrm{cm})\end{array}$ & $\begin{array}{l}\text { AVS-S } \\
\text { (wt. \%) }\end{array}$ & $\begin{array}{l}\text { Pyrite-S } \\
\text { (wt. \%) }\end{array}$ & $\begin{array}{l}\mathrm{Fe}_{\mathrm{HCl}} \\
(\mathrm{ppm})\end{array}$ & DOS & $\begin{array}{c}\delta^{34} \mathrm{~S}_{\mathrm{AVS}} \\
(\% 0)\end{array}$ & $\begin{array}{c}\delta^{34} S_{\text {Pyrite }} \\
(\%)\end{array}$ & $\begin{array}{c}\delta^{34} \mathrm{~S}_{\text {organic }} \\
(\% 0)\end{array}$ & $\begin{array}{c}\Delta^{34} \mathrm{~S}_{\mathrm{SO} 4-\mathrm{AVS}}{ }^{*} \\
(\% 0)\end{array}$ & $\begin{array}{c}\Delta^{34} \mathrm{~S}_{\text {SO4-Pyrite }} \\
(\% o)\end{array}$ \\
\hline & 7 & 0.18 & 0.13 & 779.5 & 0.85 & -26.2 & -21.2 & - & 53.9 & 48.9 \\
\hline & 9 & 0.20 & 0.10 & 1236.8 & 0.78 & -27.3 & -21.7 & - & 55.0 & 49.3 \\
\hline \multicolumn{11}{|c|}{ Oxic core } \\
\hline \multirow[t]{15}{*}{ Core 9} & 1 & 0.06 & 0.04 & 910.8 & 0.62 & -26.3 & - & -16.5 & 48.8 & - \\
\hline & 3 & 0.08 & 0.05 & 1086.3 & 0.62 & -29.6 & - & -16.9 & 52.1 & - \\
\hline & 5 & 0.19 & 0.06 & 3085.7 & 0.56 & -29.6 & - & - & 52.1 & - \\
\hline & 7 & 0.15 & 0.06 & 3427.0 & 0.48 & -29.5 & - & - & 52.0 & - \\
\hline & 9 & 0.08 & 0.06 & 4878.7 & 0.28 & -30.4 & - & - & 52.9 & - \\
\hline & 11 & 0.06 & 0.03 & 1205.7 & 0.52 & -31.4 & - & - & 54.0 & - \\
\hline & 13 & 0.10 & - & 635.5 & - & -32.0 & - & - & 54.5 & - \\
\hline & 15 & 0.03 & 0.02 & 504.5 & 0.59 & -33.3 & - & & 55.8 & - \\
\hline & 17 & 0.05 & 0.02 & 224.7 & 0.81 & -33.5 & - & - & 56.0 & - \\
\hline & 19 & 0.07 & 0.03 & 398.5 & 0.78 & -32.5 & . & - & 55.0 & - \\
\hline & 21 & 0.10 & 0.04 & 376.6 & 0.85 & -32.0 & & - & 54.5 & - \\
\hline & 23 & 0.18 & 0.04 & 329.7 & 0.91 & -34.8 & & - & 57.3 & - \\
\hline & 25 & 0.11 & 0.03 & 289.3 & 0.89 & -33.6 & - & - & 56.1 & - \\
\hline & 27 & 0.26 & 0.05 & 1070.0 & 0.82 & -33.7 & - & - & 56.2 & - \\
\hline & 29 & 0.25 & 0.05 & 682.0 & 0.88 & -34.8 & - & - & 57.3 & - \\
\hline
\end{tabular}

$* \Delta^{34} \mathrm{~S}_{\text {SO4-sulfide }}$ (where sulfide is either AVS or Pyrite) for Cores 2 and 3 are referenced to the average $\delta^{34} \mathrm{~S}$ of pore water sulfate below the chemocline $\left(\Delta^{34} \mathrm{~S}=27.6 \%\right.$ - $\left.\delta^{34} \mathrm{~S}_{\text {sulfide }}\right)$ and the isotopic offset for Core 9 is relative to pore water sulfate above the chemocline $\left(\Delta^{34} \mathrm{~S}=22.5 \% 0-\delta^{34} \mathrm{~S}_{\text {sulfide }}\right)$. 
1 Table 3. Concentration and isotope data for pore waters extracted from Mahoney Lake sediment

2 cores recovered below the chemocline (Anoxic cores) and above the interface (Oxic core).

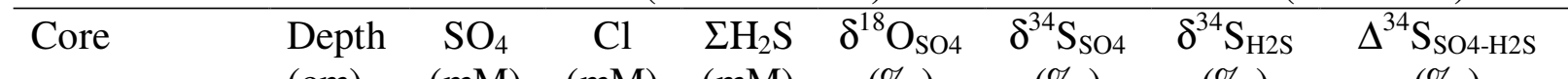

\begin{tabular}{|c|c|c|c|c|c|c|c|c|}
\hline \multicolumn{9}{|c|}{ Anoxic cores } \\
\hline \multirow[t]{8}{*}{ Core 2} & 3 & 409.8 & 63.9 & 11.68 & 18.1 & 27.4 & -18.7 & 46.2 \\
\hline & 5.5 & 505.3 & 67.2 & 12.51 & 19.3 & 26.6 & -21.5 & 48.1 \\
\hline & 6.5 & 418.5 & 64.0 & 20.68 & 18.8 & 27.4 & -22.4 & 49.7 \\
\hline & 7.5 & 427.5 & 66.5 & 20.29 & 19.2 & 27.2 & -23.6 & 50.8 \\
\hline & 9.5 & 428.0 & 66.4 & 17.40 & - & 28.5 & -20.5 & - \\
\hline & 15.5 & 447.4 & 69.3 & 4.67 & - & 28.4 & & - \\
\hline & 19.5 & - & - & 6.05 & - & - & - & - \\
\hline & 26.5 & - & - & 0.56 & - & . & & - \\
\hline \multirow[t]{15}{*}{ Core 3} & 0.5 & 468.0 & 69.4 & 18.03 & 19.9 & 28.2 & -21.0 & 49.2 \\
\hline & 1.5 & 454.0 & 69.7 & 21.36 & - & & - & - \\
\hline & 2.5 & 431.4 & 71.7 & 17.71 & - & & - & - \\
\hline & 5.5 & 453.5 & 70.0 & 15.44 & - & . & - & - \\
\hline & 6.5 & 422.3 & 69.8 & 28.15 & 20.4 & 27.9 & -22.6 & 50.5 \\
\hline & 7.5 & 445.8 & 69.4 & 3.80 & 19.6 & 28.1 & -20.6 & 48.6 \\
\hline & 8.5 & - & - & - & 18.4 & 27.6 & -25.1 & 52.7 \\
\hline & 9.5 & 457.5 & 69.2 & 21.38 & 21.3 & 28.5 & -25.0 & 53.5 \\
\hline & 15 & 466.7 & 66.9 & 7.03 & - & - & - & - \\
\hline & 21 & 473.0 & 69.8 & 15.83 & - & - & - & - \\
\hline & 41 & 459.1 & 64.2 & 15.48 & - & - & - & - \\
\hline & 53 & 481.7 & 66.7 & 15.80 & - & - & - & - \\
\hline & 59 & 430.6 & 68.1 & 18.66 & - & - & - & - \\
\hline & 73 & 440.5 & 68.2 & 8.41 & - & - & - & - \\
\hline & 83 & 510.7 & 68.2 & 20.86 & - & - & - & - \\
\hline \multicolumn{9}{|c|}{ Oxic core } \\
\hline \multirow[t]{15}{*}{ Core 9} & 1 & 321.1 & 55.5 & 1.44 & 17.8 & 22.2 & -17.8 & 40.1 \\
\hline & & 301.5 & 50.9 & 1.85 & - & 22.6 & -30.0 & 52.7 \\
\hline & & 300.6 & 48.7 & 2.14 & 17.3 & 22.6 & -24.6 & 47.3 \\
\hline & 7 & 305.5 & 49.5 & 0.62 & - & 23.1 & -28.3 & 51.5 \\
\hline & 9 & 292.8 & 47.3 & 1.95 & 17.5 & 22.4 & -25.4 & 47.8 \\
\hline & 11 & 306.5 & 46.7 & 1.93 & - & 22.5 & -25.2 & 47.7 \\
\hline & 13 & 300.3 & 50.3 & 1.31 & 17.6 & 22.5 & -27.0 & 49.5 \\
\hline & 15 & 299.9 & 51.1 & 1.87 & - & 22.6 & -29.9 & 52.5 \\
\hline & 17 & 296.3 & 52.3 & 1.85 & 17.9 & 22.5 & -28.7 & 51.2 \\
\hline & 19 & 297.1 & 50.5 & 1.80 & - & 22.6 & -29.0 & 51.6 \\
\hline & 21 & 296.3 & 53.0 & 1.75 & 17.4 & 22.4 & -36.0 & 58.4 \\
\hline & 23 & 303.4 & 52.2 & 1.70 & - & 22.4 & -33.6 & 55.9 \\
\hline & 25 & 295.0 & 52.6 & 1.38 & 17.7 & 22.7 & -34.5 & 57.2 \\
\hline & 27 & 293.5 & 52.6 & 1.90 & - & 22.5 & - & - \\
\hline & 29 & 290.3 & 57.3 & 1.38 & - & 22.3 & -30.2 & 52.5 \\
\hline
\end{tabular}

